\title{
A Review on Chitosan for the Removal of Heavy Metals Ions
}

\author{
Qasim Zia $^{\mathrm{a}}$, Madeeha Tabassum ${ }^{\mathrm{b}}$, Hugh Gong ${ }^{\mathrm{a}}$, Jiashen Li ${ }^{\mathrm{a}, *}$ \\ a The University of Manchester, Department of Materials, M13 9PL, Manchester, UK \\ ${ }^{\mathrm{b}}$ Queen Mary University of London, School of Engineering and Materials Science, London, UK
}

\begin{abstract}
There has recently been an increasing interest in water treatment methods as a result of growing concerns over shortages of clean water. This paper aims to review the past and present researches on chitosan for the adsorption of heavy metals from the wastewater. Adsorption is considered to be the most efficient method for the removal of metal impurities from drinking water. Chitosan, a deacetylated derivative of chitin, has many commercial applications due to its biocompatibility, nontoxicity, and biodegradability. Moreover, amine groups are present on the backbone of chitosan. For this reason, chitosan has been used for the adsorption of heavy metals. To begin with, mechanism of adsorption of heavy metal ions on chitosan and disadvantages of heavy metal ions were reviewed. Further, a detailed review had been done on the adsorption capacities of crosslinked chitosan, chitosan nanofibers, chitosan nanoparticles, chitosan composites, modified/pure chitosan, and porous chitosan. Lastly, research gaps and future recommendations were given for further development and accurate results of adsorption.
\end{abstract}

Keywords: Chitosan; Heavy Metals; Adsorption; Crosslinked Chitosan

\section{Introduction}

\subsection{The Chemical Construction of Chitosan}

Chitosan is linear amino polysaccharide consisting of two basic units, glucose amine and N-acetyl glucosamine, acquired from the deacetylation of chitin in the alkaline environment [1]. Chitin is a natural polymer discovered 200 years ago. It is mainly extracted from cell walls of fungi as well as from the exoskeleton of crustaceans such as shrimp and crabs [2-6]. The structure of chitosan is composed of $(1,4)$-linked 2 -amino-2-deoxy- $\beta$-D-glucan as shown in Fig. 1 , its chemical name is poly [-(1, 4)-2-amino-2-deoxy-D-glucopiranose] $[2,7,8]$. The structures of chitosan contain amine $\left(\mathrm{NH}_{2}\right)$ groups, and as a result have good medical properties for instance biodegradability, biocompatibility and excellent antibacterial activity. It is the only cationic natural occurring

${ }^{*}$ Corresponding author.

Email address: jiashen.li@manchester.ac.uk (Jiashen Li). 
polymer [9, 10]. Furthermore, chitosan is extensively used for the adsorption of heavy metal ions due to the presence of amine and hydroxyl groups [11-13].

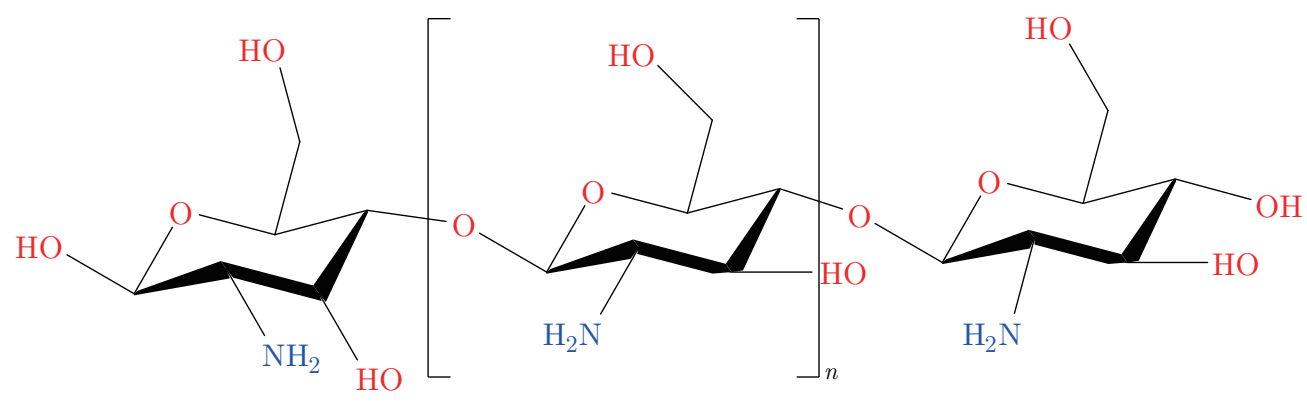

Fig. 1: Chemical construction of chitosan

\subsection{Adsorption at Solid/Liquid Interface}

Solids and many solvents which do not dissolve in solution and has the tendency to form bonds with the ions present in solution are called ion exchangers; and the process of ion exchange that occurs at solid/liquid interface is known as ion exchange adsorption. Fig. 2 shows the schematic representation of adsorption solid/liquid interface. Various ion exchange minerals exist in nature such as: alumina silicates from zeolite group and clays of bentonite and montmorillonite.

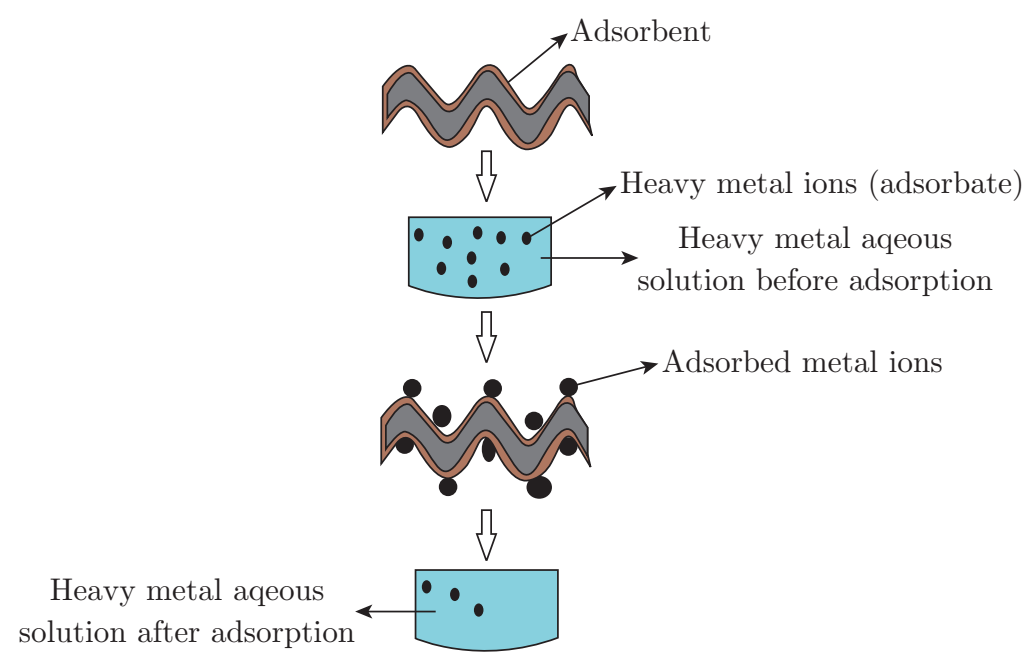

Fig. 2: Schematic representation of adsorption at solid/liquid interface

There are three main types of ion exchanger's i.e. natural, semisynthetic and synthetic ion exchangers. Natural ion exchange materials were the first which found the applications in the purification of water. Bentonite clay and zeolites are common ion exchange materials. An example of zeolite structure is aluminate $\mathrm{AlO}_{4}$ in which $\mathrm{Al}^{3+}$ ions are surrounded in tetrahedral by double negative charge of oxygen ions or $\mathrm{OH}^{-}$groups with single negative charge. These excess negative charges are balanced with alkali metals or alkaline earth metal ions which are loosely bound with the crystal lattice. These metal ions can be displaced or substituted with the ions present in solution [14]. 
Semisynthetic ion exchangers are natural materials which have been subjected to chemical treatment. Sulfonated coal is regarded as typical semisynthetic ion exchange material, which is obtained by the sulfonation of natural coal by using concentrated sulphuric acid. It has been studied that cation exchangers with having high adsorption capacity can be obtained from certain types of coal [15].

Synthetic ion exchangers can be obtained by either inorganic or organic synthesis routes. An example of synthetic cation exchanger is made by inorganic synthesis is aluminosilicates type but of different chemical compositions depending upon the raw materials used for production. They have general composition:

$$
\mathrm{Al}_{2} \mathrm{O}_{3} \cdot\left(\mathrm{SiO}_{2}\right)_{\mathrm{x}} \cdot\left(\mathrm{Na}_{2} \mathrm{O}\right)_{\mathrm{y}} \cdot\left(\mathrm{H}_{2} \mathrm{O}\right)_{\mathrm{z}}
$$

Currently available ion exchangers are synthesized by organic route. There are synthetic resins which are insoluble in water, alcohols, ethers and some hydrocarbons. They have high exchange capacity and greater tensile strength and chemical resistance which make them suitable for many applications [15]. They can be cationic or anionic in nature; their composition can be represented as:

$$
\begin{array}{ll}
\mathrm{R}-\mathrm{A}^{-} \mathrm{Me}^{+} & \mathrm{R}-\mathrm{B}^{+} \mathrm{X}^{-} \\
\text {(CationExchanger) } & \text { (AnionExchanger) }
\end{array}
$$

where $\mathrm{R}$ is the polymer frame, $\mathrm{A}^{-}$is anionic group such as $-\mathrm{COO}^{-}$attached to the polymer by atomic bond, $\mathrm{Me}^{+}$is the cation, it can be a metal ion or $\mathrm{H}^{+}$ion bonded with the anion by an ionic bond and is capable to be changed. Similarly, $\mathrm{B}^{+}$is cationic group e.g. $\mathrm{NH}_{2}^{+}$and $\mathrm{X}^{-}$is an anion like $\mathrm{OH}^{-}$.

\subsection{Complex Formation of Chitosan with Heavy Metal Ions}

The ability of chitosan to adsorb metal ions through forming complexes was discovered when researchers expressed interest in it [16-19]. Studies show that the complexation ability of chitosan is influenced by its physical state, when it is in the form of powder, gel, fibre, particles or films [20, 21]. The degree of acetylation is however considered to be the major factor in the complexation process, proved by Micera [22] and Kurita [23].

Potentiometry is considered to be the fundamental method to describe the complex formation of chitosan with metals by studying acid-base reactions and metal-ligand interactions. The acid accepts a pair of the electron (metal) from the base (chitosan) and forms a covalent bond with the metallic ions. The only one free site available in chitosan monomeric unit, amine groups, initiates the covalent bonds with metallic ions. Equations (1), (2) and (3) described the interaction of chitosan with metals [21].

$$
\begin{aligned}
& \text { Chitosan }-\mathrm{NH}_{2}+\mathrm{H}_{3} \mathrm{O}^{+} \rightleftharpoons \text { Chitosan }-\mathrm{NH}_{3}^{+}+\mathrm{H}_{2} \mathrm{O} \\
& \text { Chitosan }-\mathrm{NH}_{2}+\mathrm{M}^{\mathrm{n}+} \rightleftharpoons(\text { Complex })^{\mathrm{n}+} \\
& \text { Chitosan }-\mathrm{NH}_{3}^{+}+\mathrm{M}^{\mathrm{n}+}+\mathrm{H}_{2} \mathrm{O} \rightarrow(\text { Complex })^{\mathrm{n}+}+\mathrm{H}_{3} \mathrm{O}^{+}
\end{aligned}
$$

M. Rhazi et al [19] studied the adsorption process of copper at different $\mathrm{pH}$ values. It was discovered that when the $\mathrm{pH}$ of a solution is less than 5.30 there was no or very small complex 
formed between copper $\mathrm{Cu}(\mathrm{II})$ ions and chitosan. When $\mathrm{pH}$ is greater than 5.30, amino groups made a covalent bond with copper ions and formed $\left[\mathrm{Cu}\left(-\mathrm{NH}_{2}\right)\right]^{2+}$ complex as shown in Fig. 3 and in the following equation (4) and (5):

$$
\begin{aligned}
& \mathrm{Cu}^{2+}+-\mathrm{NH}_{3}^{+}+\mathrm{H}_{2} \mathrm{O} \rightleftharpoons\left[\mathrm{Cu}\left(-\mathrm{NH}_{2}\right)\right]^{2+}+\mathrm{H}_{3} \mathrm{O}^{+} \\
& \mathrm{Cu}^{2+}+-\mathrm{NH}_{2} \rightleftharpoons\left[\mathrm{Cu}\left(-\mathrm{NH}_{2}\right)\right]^{2+}
\end{aligned}
$$
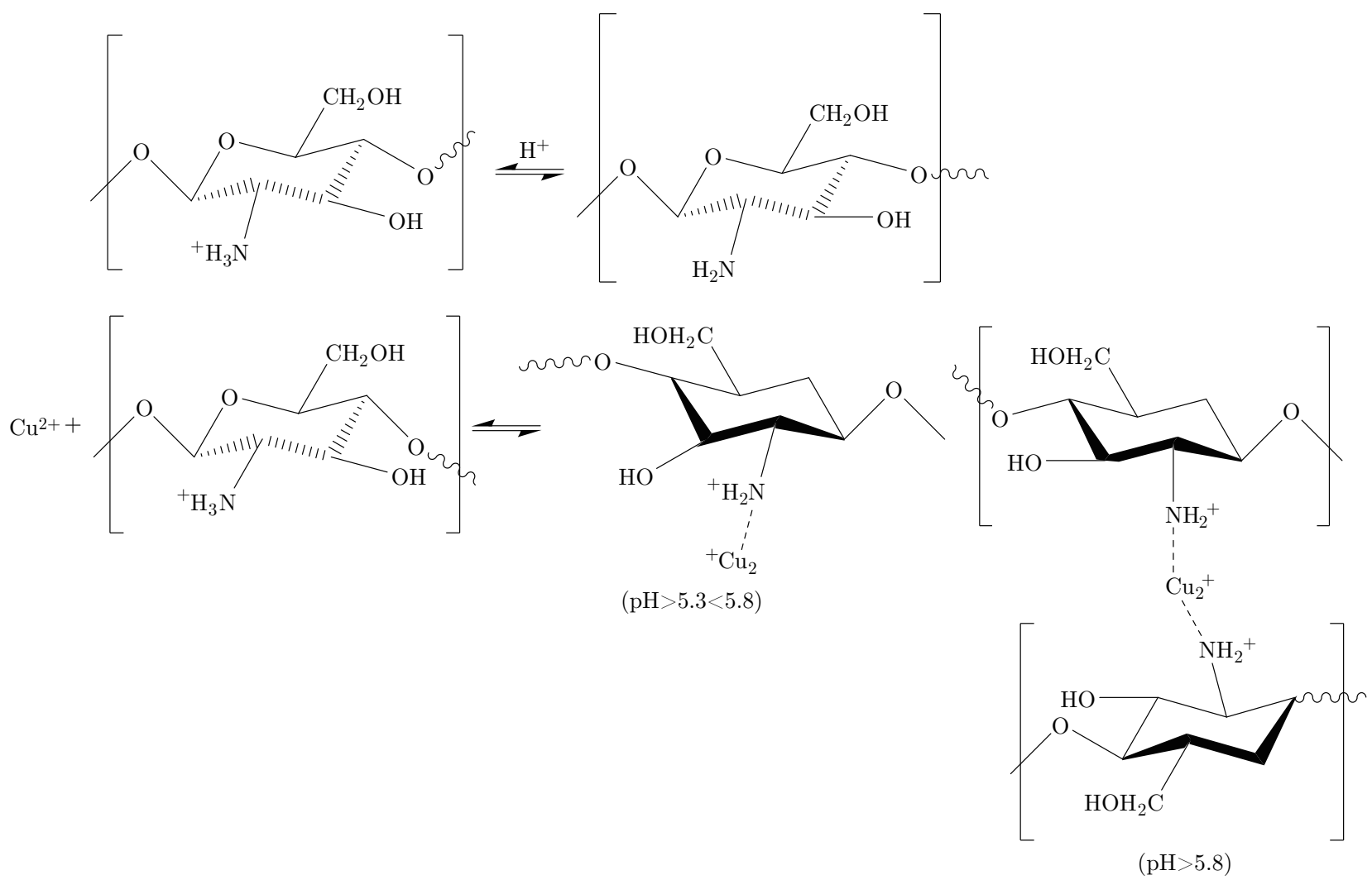

Fig. 3: Structures of chitosan-copper complexes

Another type of complex was also investigated when $\mathrm{pH}$ goes above 5.80 where another amino group is incorporated $\left[\mathrm{Cu}\left(-\mathrm{NH}_{2}\right)_{2}\right]^{2+}$ as shown in Fig. 2 and in the equations (6) and (7).

$$
\begin{aligned}
& {\left[\mathrm{Cu}\left(-\mathrm{NH}_{2}\right)\right]^{2+}+-\mathrm{NH}_{3}^{+}+\mathrm{H}_{2} \mathrm{O} \rightleftharpoons\left[\mathrm{Cu}\left(-\mathrm{NH}_{2}\right)_{2}\right]^{2+}+\mathrm{H}_{3} \mathrm{O}^{+}} \\
& {\left[\mathrm{Cu}\left(-\mathrm{NH}_{2}\right)\right]^{2+}+-\mathrm{NH}_{2} \rightleftharpoons\left[\mathrm{Cu}\left(-\mathrm{NH}_{2}\right)_{2}\right]^{2+}}
\end{aligned}
$$

This complex is stable up to $\mathrm{pH} 7.7$; beyond this $\mathrm{pH}$, copper hydroxides will precipitate and the procedure will become difficult to study.

\subsection{Heavy Metal Ions Pollution in Water}

Currently there are many industries discharging high quantities of heavy metals into the environment. The main sources of heavy metal ions are shown in Fig. 4. These metallic ions cause toxicity to both the ecosystem and human beings. As a result, the international community is now giving more attention to heavy metal pollution [24-27]. 


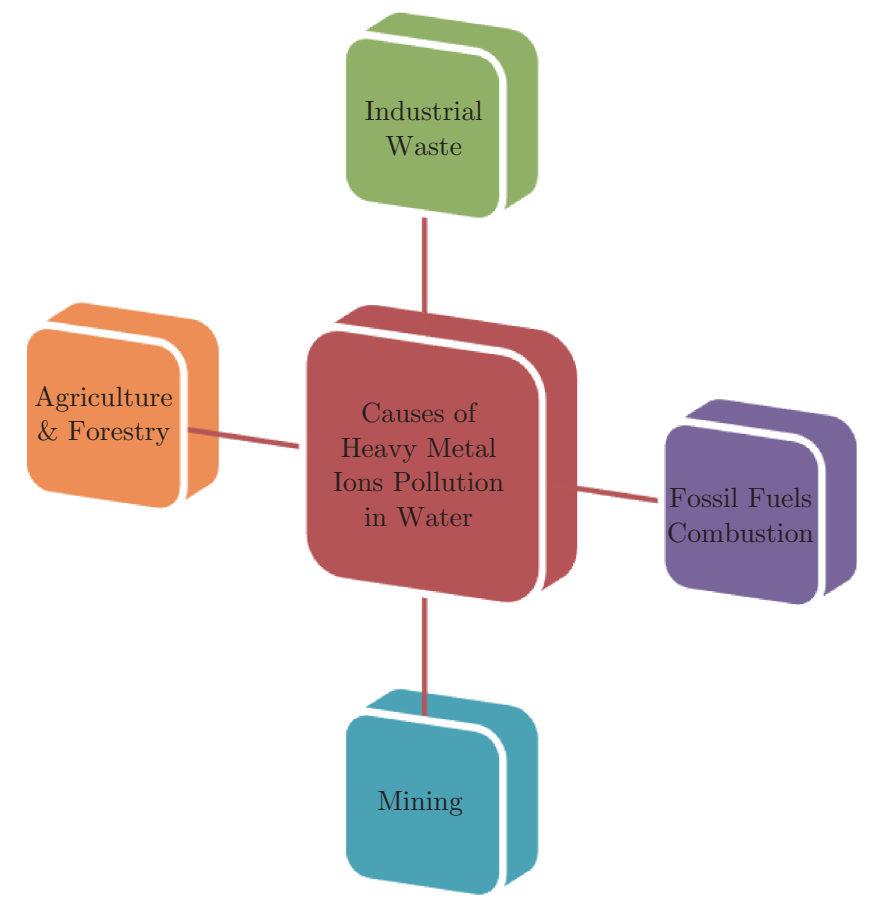

Fig. 4: Causes of heavy metal ions pollution in water

One of the major problems that has become a serious concern is water pollution due to heavy metals [28]. Very minute amount of heavy metals can cause serious water pollution due to their high toxicity and non-biodegradable nature [29-31]. Heavy metals also have the tendency to accumulate in living organisms, which is harmful for public health and may cause many disorders and diseases [32-36]. For example, lead $\mathrm{Pb}(\mathrm{II})$ which is mostly found in textile dyeing, ceramics and glass industries, petroleum refining, battery manufacture and mining operations etc., [37, 38] can cause mental disorders and semi-permanent damage to the brain [39]. Cadmium $\mathrm{Cd}(\mathrm{II})$ is another pollutant that is a product of metal plating, metallurgical alloying, mining and ceramics operations [40]. It causes a wide-range of syndromes such as renal dysfunction, hypertension, hepatic injury, lung damage and teratogenic effects [41]. Likewise, exposure of excess nickel $\mathrm{Ni}(\mathrm{II})$ in the human body can cause lungs, cardiovascular and kidney diseases [42, 43]. Chromium $\mathrm{Cr}$ (VI) is also a well-known carcinogen. In July 2008, the US national toxicology program showed clear evidence of carcinogenic activity of chromium [44]. It is extensively used in industries like chromate production, chromate pigment production and chrome plating [45, 46]. Studies have shown that lung cancer occurrences are increasing among workers of these industries [4749]. Copper $\mathrm{Cu}(\mathrm{II})$ is an important nutrient which is fused in many metalloenzymes responsible for haemoglobin formation and cross-linking of collagen, elastin and hair keratin, but in redox reactions copper has the ability to reduce from a $\mathrm{Cu}(\mathrm{II})$ to $\mathrm{Cu}(\mathrm{I})$ state which is toxic. This is due to the generation of super hydroxides and hydroxyl radicals during reduction [50-53]. Zinc $\mathrm{Zn}$ (II) is also a vital metal for biological functions. But, when it is used in high concentrations it becomes toxic to animals, ecosystem and can cause nausea, anaemia and pancreas loss [54]. Its main sources are from battery production, galvanic industries mining effluents and acid amine drainage $[55,56]$. Among metal pollutants mercury $\mathrm{Hg}(\mathrm{II})$ is the most problematic. Nonferrous and ferrous metal production are common sources of $\mathrm{Hg}$ (II) pollution [57]. $\mathrm{Hg}$ (II) manifested critical health disasters in Japan and Iraq [58-61]. Excess of $\mathrm{Hg}$ (II) ions is responsible for brain, gut lining and kidney failure [59]. 


\section{Crosslinked Chitosan for the Removal of Heavy Metal Ions}

In crosslinked chitosan, polymeric chains are interconnected with cross linkers, leading to the formation of a 3D network.

Chitosan was crosslinked with diethylenetriaminepentacetic acid when eliminating $\mathrm{Cr}(\mathrm{VI})$ ions from aqueous solution [62]. In another study, chitosan was crosslinked with trimesic acid for a similar purpose [63]. The adsorption coefficient was discovered to be higher with the latter crosslinking acid i.e. $192.3 \mathrm{mg} / \mathrm{g}$ and $129.53 \mathrm{mg} / \mathrm{g}$ when compared with theformer at an optimized $\mathrm{pH}$ of 3 and 2. Furthermore, both were discovered to be beneficial for removing $\mathrm{Pb}(\mathrm{II})$ and Fe(II) ions from chrome plating effluent. Chitosan (CS)/Polyvinyl Alcohol (PVA) physically crosslinked nanoparticles were developed for the adsorption of manganese $\mathrm{Mn}$ (II) ions from an aqueous solution. $\mathrm{Mn}$ (II) is a major pollutant, which affects the colour, taste and odour of water. The adsorption capability of $\mathrm{Mn}$ (II) ions on CS/PVA nanoparticles was studied as a function of $\mathrm{pH}$, adsorbent dose, contact time and different concentrations of solutions [64]. Adsorbent dose had a major effect on the removal of heavy metal ions; this can be attributed to the enhanced surface and more binding sites on CS/PVA nanoparticles. It was found that $83.5 \%$ metals ions were removed for $20 \mathrm{mg} / \mathrm{L}$ at $0.8 \mathrm{~g}$ in $100 \mathrm{~mL}$, which is similar to their earlier studies on the removal of $\mathrm{Mn}(\mathrm{II})$ ions from water [65].

In a different study, epichlorohydrin was chosen to crosslink with chitosan for the adsorption of $\mathrm{Cu}(\mathrm{II}), \mathrm{Pb}(\mathrm{II})$ and $\mathrm{Zn}(\mathrm{II})$ ions from an aqueous solution. The adsorption capacity for $\mathrm{Cu}(\mathrm{II})$ $(35.40 \mathrm{mg} / \mathrm{g})$ was found to be highest when compared to $\mathrm{Pb}(\mathrm{II})(13.05 \mathrm{mg} / \mathrm{g})$ and $\mathrm{Zn}$ (II) (10.21 $\mathrm{mg} / \mathrm{g}$ ) [66]. However, when compared to pure chitosan, crosslinking has a negative effect on the adsorption of $\mathrm{Pb}(\mathrm{II})$ and $\mathrm{Zn}$ (II) ions, decreasing their removal efficiencies up to $6.39 \%$ and $1.07 \%$. However in the case of $\mathrm{Cu}(\mathrm{II})$, it showed an increase in efficiency by more than twofold [67]. Similar studies on the adsorption of $\mathrm{Cu}$ (II), $\mathrm{Pb}$ (II) and $\mathrm{Zn}$ (II) by chitosan crosslinked with glutaraldehyde exhibited correlates with the results in [68]. Table 1 shows the maximum adsorption capacities of crosslinked chitosan.

\section{Chitosan Composites for the Removal of Heavy Metal Ions}

To enhance the removal and adsorption efficiency of hexavalent $\mathrm{Cr}(\mathrm{VI})$ ions, chitosan, graphene oxide and 1, 2-cyclohexylenedinitrilotetraacetic acid nanocomposite was synthesized for the first time. Graphene has more free groups available for adsorption i.e. hydroxyl, carboxyl and epoxy, which results in improved adsorption of heavy metals from aqueous solutions. Maximum adsorption of $166.98 \mathrm{mg} / \mathrm{g}$ for $\mathrm{Cr}(\mathrm{VI})$ ions was achieved in optimized conditions of $\mathrm{pH}$, temperature and time [74]. In previously reported studies on the adsorption of $\mathrm{Cr}$ (VI) ions by chitosan composites, the highest adsorption capacity of $153.85 \mathrm{mg} / \mathrm{g}$ was reported [75]. In a further study, chitosan/organoclay composites were developed and the removal efficiency was also found to be less than an above-reported study that is $128.43 \mathrm{mg} / \mathrm{g}$ [76]. The adsorption capacity of chitosan can be varied by degree of deacetylation [77]. Habiba et al. studied the degree of effectiveness for the deacetylation of chitosan in chitosan/PVA $/ \mathrm{TiO}_{2}$ nanocomposites. They proved that a degree of deacetylation increased the adsorption efficiency of the composite. This is evident from the 
Table 1: Maximum removal ability for heavy metal ions of crosslinked chitosan

\begin{tabular}{|c|c|c|c|c|c|}
\hline $\begin{array}{l}\text { Sr. } \\
\text { No. }\end{array}$ & Type of Adsorbent & $\begin{array}{l}\text { Adsorbate } \\
\text { Ions }\end{array}$ & $\begin{array}{l}\text { Maximum Adsorption } \\
\qquad\left(\mathrm{q}_{\max }\right) \mathrm{mg} / \mathrm{g}\end{array}$ & $\begin{array}{l}\text { Optimum } \mathrm{pH} \\
\text { for Adsorption }\end{array}$ & Reference \\
\hline \multirow[t]{2}{*}{1} & \multirow[t]{2}{*}{ Chitosan-clay/Epicholorhydrin } & $\mathrm{Ni}(\mathrm{II})$ & 32.36 & 6.0 & {$[69]$} \\
\hline & & $\mathrm{Cd}(\mathrm{II})$ & 72.31 & & \\
\hline 2 & Chitosan-PVA/Glutaraldehyde & $\mathrm{Cd}(\mathrm{II})$ & 142.9 & 6.0 & {$[70]$} \\
\hline 3 & Chitosan/Silica & $\mathrm{Cr}(\mathrm{VI})$ & $28.88,23.40$ & $5.0-6.0$ & {$[71]$} \\
\hline \multirow[t]{2}{*}{4} & \multirow[t]{2}{*}{ Chitosan-halomonas/Glutaraldehyde } & $\mathrm{Pb}(\mathrm{II})$ & 24.15 & $5.0-7.0$ & {$[72]$} \\
\hline & & $\mathrm{Cd}(\mathrm{II})$ & 23.88 & & \\
\hline \multirow[t]{7}{*}{5} & \multirow{7}{*}{$\begin{array}{l}\text { Chitosan/6, 6-piperazine-1, } \\
\text { 4-diyldimethylenebis } \\
\text { (4-methyl-2-formyl) phenol }\end{array}$} & $\mathrm{Cu}(\mathrm{II})$ & 76.88 & $6.5-8.5$ & {$[73]$} \\
\hline & & $\mathrm{Ni}(\mathrm{II})$ & 38.15 & & \\
\hline & & $\mathrm{Co}(\mathrm{II})$ & 27.11 & & \\
\hline & & $\operatorname{Mn}(\mathrm{II})$ & 23.62 & & \\
\hline & & $\mathrm{Fe}(\mathrm{II})$ & 23.45 & & \\
\hline & & $\mathrm{Cd}(\mathrm{II})$ & 58.45 & & \\
\hline & & $\mathrm{Pb}(\mathrm{II})$ & 84.94 & & \\
\hline \multirow[t]{3}{*}{6} & \multirow[t]{3}{*}{ Chitosan/Epichlorohydrin } & $\mathrm{Cu}(\mathrm{II})$ & 35.46 & 6.0 & {$[11]$} \\
\hline & & $\mathrm{Zn}(\mathrm{II})$ & 10.21 & & \\
\hline & & $\mathrm{Pb}(\mathrm{II})$ & 34.13 & & \\
\hline
\end{tabular}

presence of $\mathrm{NH}_{2}$ groups in deacetylated chitosan which functions as essential sites for adsorption [78].

Comparative adsorption of $\mathrm{Pb}(\mathrm{II}), \mathrm{Cu}(\mathrm{II})$ and $\mathrm{Cd}(\mathrm{II})$ ions were investigated by chitosan/montmorillonite (Mt) composite [79]. Mt was used because of its good cation exchangeability [80]. Composite was reported to have the highest adsorption capacity for $\mathrm{Pb}$ (II). The sequence of the adsorption was $\mathrm{Pb}(\mathrm{II})>\mathrm{Cu}(\mathrm{II})>\mathrm{Cd}(\mathrm{II})$. This is due to the higher electronegativity of $\mathrm{Pb}(\mathrm{II})$ (3.29) as compared to $\mathrm{Cu}$ (II) (2.98) and $\mathrm{Cd}(\mathrm{II})$ (2.71) correspondingly. This is due to the high affinity between two atoms when the electronegativity difference of $\mathrm{N}$ or $\mathrm{O}$ is smaller [81-84]. In another work, chitosan/PVA magnetic composite was prepared by co-precipitation method [85] for the adsorption of $\mathrm{Cu}(\mathrm{II})$ ions. This composite can adsorb up to $143.0 \mathrm{mg} / \mathrm{g}$ of $\mathrm{Cu}$ (II) ions from wastewater [86].

A novel composite Chitosan/Hydroxyapatite membrane was prepared for removal of $\mathrm{Pb}(\mathrm{II})$, $\mathrm{Co}(\mathrm{II})$ and $\mathrm{Ni}(\mathrm{II})$ ions from aqueous solutions. Composite membrane demonstrated maximum adsorption ability for $\mathrm{Pb}(\mathrm{II})$ i.e. $296.7 \mathrm{mg} / \mathrm{g}$ as compared to $\mathrm{Ni}(\mathrm{II})(213.8 \mathrm{mg} / \mathrm{g}$ ) and $\mathrm{Co}(\mathrm{II})$ $(180.2 \mathrm{mg} / \mathrm{g})$ [87]. In comparison to other studies, chitosan/clinoptilolite composite membrane claimed the highest adsorption of $\mathrm{Co}(\mathrm{II})(467.9 \mathrm{mg} / \mathrm{g})$ [88] and chitosan/silica have enhanced the ability to adsorbed Ni(II) $(254.3 \mathrm{mg} / \mathrm{g})$ [89]. Further studies showed that chitosan/hydroxyapatite 
Table 2: Maximum removal ability for heavy metal ions of chitosan composites

\begin{tabular}{|c|c|c|c|c|c|}
\hline $\begin{array}{l}\text { Sr. } \\
\text { No. }\end{array}$ & Type of Adsorbent & $\begin{array}{l}\text { Adsorbate } \\
\text { Ions }\end{array}$ & $\begin{array}{l}\text { Maximum } \\
\text { Adsorption } \\
\left(\mathrm{q}_{\max }\right) \mathrm{mg} / \mathrm{g}\end{array}$ & $\begin{array}{l}\text { Optimum pH } \\
\text { for Adsorption }\end{array}$ & Reference \\
\hline 1 & Chitosan/CDTA/GO & $\mathrm{Cr}(\mathrm{VI})$ & 166.98 & $2.0-3.0$ & {$[74]$} \\
\hline 2 & Chitosan/Clay & $\mathrm{Cu}(\mathrm{II})$ & 181.5 & 7.0 & {$[91]$} \\
\hline \multirow[t]{4}{*}{3} & \multirow[t]{4}{*}{ Chitosan/Alumina } & $\mathrm{Cu}(\mathrm{II})$ & 86.2 & 4.0 & {$[25,92]$} \\
\hline & & $\mathrm{Ni}(\mathrm{II})$ & 78.1 & & \\
\hline & & As(III) & 56.50 & & \\
\hline & & $\operatorname{As}(\mathrm{V})$ & 96.46 & & \\
\hline 4 & Chitosan/Glucosamine & $\mathrm{Cr}(\mathrm{VI})$ & 153.85 & 4.0 & {$[75]$} \\
\hline 5 & Chitosan/Graphene Oxide & $\mathrm{Pb}(\mathrm{II})$ & 76.94 & 5.0 & {$[93]$} \\
\hline \multirow[t]{6}{*}{6} & \multirow[t]{6}{*}{ Magnetic Chitosan } & $\mathrm{Cr}(\mathrm{VI})$ & 17.29 & $\begin{array}{c}1.0-3.5 \text { for } \\
\mathrm{Cr}(\mathrm{VI}) 6.0-7.0\end{array}$ & {$[94,95]$} \\
\hline & & $\mathrm{Pb}(\mathrm{II})$ & 27.95 & & \\
\hline & & $\mathrm{Hg}(\mathrm{II})$ & 23.03 & & \\
\hline & & $\mathrm{Cd}(\mathrm{II})$ & 27.83 & & \\
\hline & & $\mathrm{Ni}(\mathrm{II})$ & 22.07 & & \\
\hline & & $\mathrm{Cu}(\mathrm{II})$ & 216.6 & & \\
\hline 7 & Chitosan/PVA & $\mathrm{Cu}(\mathrm{II})$ & 143.0, 193.39 & 6.0 & {$[86,96]$} \\
\hline \multirow[t]{3}{*}{8} & \multirow[t]{3}{*}{ Chitosan/Sulfydryl/Grphene Oxide } & $\mathrm{Cd}(\mathrm{II})$ & 177.0 & 5.0 & {$[97]$} \\
\hline & & $\mathrm{Pb}(\mathrm{II})$ & 447.0 & & \\
\hline & & $\mathrm{Cu}(\mathrm{II})$ & 425.0 & & \\
\hline \multirow[t]{2}{*}{9} & \multirow[t]{2}{*}{ Chitosan/Anaerobic Granular Sludge } & $\mathrm{Pb}(\mathrm{II})$ & 97.97 & 6.0 & {$[98]$} \\
\hline & & $\mathrm{Cu}(\mathrm{II})$ & 83.65 & 3.0 & \\
\hline 10 & Chitosan/PVA/Silk Fibroin & $\mathrm{Pb}(\mathrm{II})$ & 194.099 & 6.0 & {$[99]$} \\
\hline 11 & Chitosan/Fe-Hydroxyapatite & $\mathrm{Pb}(\mathrm{II})$ & 1385.0 & - & {$[100]$} \\
\hline \multirow[t]{2}{*}{12} & \multirow[t]{2}{*}{ Chitosan/Magnetite } & $\mathrm{Ni}(\mathrm{II})$ & 63.33 & $4.0-6.0$ & {$[101]$} \\
\hline & & $\mathrm{Pb}(\mathrm{II})$ & 52.55 & & \\
\hline \multirow[t]{5}{*}{13} & \multirow[t]{5}{*}{ Chitosan/Perlite } & $\mathrm{Cu}(\mathrm{II})$ & 196.07 & $3.0-4.5$ & [102-105] \\
\hline & & $\mathrm{Ni}(\mathrm{II})$ & 114.94 & & \\
\hline & & $\mathrm{Cd}(\mathrm{II})$ & 178.6 & & \\
\hline & & $\mathrm{Cr}(\mathrm{VI})$ & 153.8 & & \\
\hline & & $\mathrm{Cu}(\mathrm{II})$ & 104.0 & & \\
\hline 14 & Chitosan/Silica & $\mathrm{Ni}(\mathrm{II})$ & 254.3 & 5.0 & {$[89]$} \\
\hline \multirow[t]{2}{*}{15} & \multirow[t]{2}{*}{ Chitosan/PVC } & $\mathrm{Cu}(\mathrm{II})$ & 87.9 & 4.0 & {$[106]$} \\
\hline & & $\mathrm{Ni}(\mathrm{II})$ & 120.5 & & \\
\hline \multirow[t]{2}{*}{16} & \multirow[t]{2}{*}{ Chitosan/Sand } & $\mathrm{Cu}(\mathrm{II})$ & $10.87,8.18$ & 4.2 & {$[107]$} \\
\hline & & $\mathrm{Pb}(\mathrm{II})$ & 12.32 & & \\
\hline 17 & Chitosan/Montmorillonite & $\mathrm{Cr}(\mathrm{VI})$ & 41.67 & 4.0 & {$[108]$} \\
\hline 18 & Chitosan/Alginate & $\mathrm{Cu}(\mathrm{II})$ & 67.66 & 6.0 & {$[109]$} \\
\hline 19 & Chitosan/Calcium Alginate & $\mathrm{Ni}(\mathrm{II})$ & 222.2 & 5.0 & {$[89]$} \\
\hline
\end{tabular}


composite was used for removal of $\mathrm{Fe}(\mathrm{II})$ ions from drinking water and adsorption capacity of 6.753 $\mathrm{mg} / \mathrm{g}$ was reported [90].

In a different research, chitosan/clinoptilolite composite claimed to have good adsorption capacity against Uranium $\left(\mathrm{UO}_{2}^{2+}\right)$ and Thorium $\left(\mathrm{Th}^{4+}\right)$ ions from radioactive solutions. The maximum adsorption for $\mathrm{Th}^{4+} 328.32 \mathrm{mg} / \mathrm{g}$ and $408.62 \mathrm{mg} / \mathrm{g}$ for $\mathrm{UO}_{2}^{2+}$ ions were recorded [110]. Similar material was also used by incorporating zeolite particles for the removal of $\mathrm{Cu}(\mathrm{II}), \mathrm{Co}(\mathrm{II})$ and $\mathrm{Ni}(\mathrm{II})$ ions in further studies and the highest adsorption capacity $11.32 \mathrm{mmol} / \mathrm{g}, 7.94 \mathrm{mmol} / \mathrm{g}$ and $4.4209 \mathrm{mmol} / \mathrm{g}$ was reported $[111,88,112]$. Table 2 illustrates the maximum adsorption capacities of chitosan composite.

\section{Chitosan Nanofibers for the Removal of Heavy Metal Ions}

Polyethylene oxide (PEO)/CS nanofibers were tested for their capacity to adsorb $\mathrm{Ni}$ (II), $\mathrm{Cu}(\mathrm{II})$, $\mathrm{Pb}(\mathrm{II})$ and $\mathrm{Cd}(\mathrm{II})$ heavy metals from water. Under optimal conditions of $\mathrm{pH}$, temperature and time, results showed the adsorption potential of nanofibers in increasing order, $\mathrm{Ni}$ (II) $>\mathrm{Cu}$ (II) $>$ $\mathrm{Cd}(\mathrm{II})>\mathrm{Pb}(\mathrm{II})$. This is due to smaller ionic radius of ions, as radius decreases charge density will increase and number of available sites for adsorption would be enhanced. Therefore, adsorption efficiencies were obtained $89 \%, 82 \%, 72 \%$ and $68 \%$ for $\mathrm{Ni}(\mathrm{II}), \mathrm{Cu}(\mathrm{II}), \mathrm{Cd}(\mathrm{II})$ and $\mathrm{Pb}(\mathrm{II})$ [113]. Similar nanofibers were also used for adsorption of $\mathrm{Cu}$ (II) ions from water used in paper making industry. They found to be highly efficient adsorbent for copper ions with $94.7 \%$ removal efficiency by using only $75 \mathrm{mg}$ of nanofibers [114].

In previous studies slow adsorption rate of chitosan/PVA nanofibers was reported [115]. To improve rate of adsorption, zeolite nanoparticles were incorporated in nanofibers, these nanofibers proved to adsorb chromium, nickel and iron ions rapidly with maximum removal efficiencies of about $100 \%$ [116]. Ionic radius of these metals in decreasing order are $\mathrm{Cr}$ (VI) $<\mathrm{Fe}(\mathrm{III})<\mathrm{Ni}$ (II) [117]. Adsorption was also reported in the similar sequence. Moreover, researchers also studied the effect of degree of deacetylation (DD) of chitosan/PVA nanofibers for adsorption of chromium and iron metal ions. They found that as DD is increased adsorption efficiency was improved for chromium due to increase in amino groups. On the contrary, adsorption efficiency was reduced for iron [118]. This was explained by low molecular weight of chitosan at higher DD due to which a polymer chain may be released from chitosan structure which creates steric hindrance with large Fe ions. Therefore, affecting the adsorption capacity [119].

Furthermore, pure chitosan nanofibers were also synthesized for adsorption of copper and lead ions. Adsorption capacity for copper and lead was $263.15 \mathrm{mg} / \mathrm{g}$ and $485.44 \mathrm{mg} / \mathrm{g}$ respectively [120]. For copper this value is 6 to 11 times higher than the capacities reported in different studies of chitosan [121-124].

\section{Chitosan Nano Particles for the Removal of Heavy Metal Ions}

Nanocomposites of chitosan/clay with silver (Ag) and gold (Au) nanoparticles were made to 
achieve maximum adsorption of $\mathrm{Cu}(\mathrm{II})$ from aqueous solution. They used the surface properties of clay to give additional active sites for adsorption including cations exchange and large surface area. Researchers claimed that there is $100 \%$ efficiency of chitosan/clay/Ag nanocomposite for the removal of copper with maximum adsorption capacity of $181.5 \mathrm{mg} / \mathrm{g}$ [91]. This capacity is higher than the previously reported highest value for the adsorption of copper ions which was $153.9 \mathrm{mg} / \mathrm{g}$ when semi-IPN based hydrogel is used based on chitosan and gelatine [129]. Furthermore, chitosan and alginate nanocomposites were prepared by ion crosslinking method for the adsorption of chromium ions from wastewater [130]. Chitosan was also crosslinked with polyacrylamide to develop nanocomposite with copper; adsorption of lead ions from aquatic solutions in environmental conditions was investigated. The maximum adsorption capacity was found to be $38.93 \mathrm{mg} / \mathrm{g}$ [131]. A novel biodegradable and non-toxic nano sorbent based on chitosan-alginate nanoparticles was developed for the removal of mercury $(\mathrm{Hg})$ ions from water. As chitosan is cationic and alginate is anionic in nature, the nano sorbent is efficient in adsorbing both negatively and positively charged heavy metal ions. Researchers claimed that it is the highest adsorption capability of this sorbent as compared to the values reported in the previous literature, where it was recorded as $217.39 \mathrm{mg} / \mathrm{g}$ at $30{ }^{\circ} \mathrm{C}$ [132]. Similarly, alginate coated chitosan nanoparticles were investigated for the removal of nickel ions from industrial effluents. It was found that $94.48 \%$ of nickel was adsorbed at a $\mathrm{pH} 3$ [133]. In another work, quaternized chitosan microspheres (QCMS) were synthesized for removal of $\mathrm{Cr}(\mathrm{VI})$ ions from wastewater. It was discovered that $97.34 \%$ of chromium was detached under the optimal condition of pH 5 [134].

Further investigations were also made on magnetic chitosan $/ \mathrm{Fe}_{3} \mathrm{O}_{4}$ nanoparticles synthesized by using gravity precipitation method. These particles were used as adsorbents for lead and cadmium ions from aqueous solutions and the maximum removal capacity was found to be $79.24 \mathrm{mg} / \mathrm{g}$ for lead and $36.42 \mathrm{mg} / \mathrm{g}$ for cadmium ions [145]. These nanoparticles proved to be most efficient for the adsorption of lead and cadmium than any other reported studies on $\mathrm{Fe}_{3} \mathrm{O}_{4}$ nanoparticles with different materials [146-148, 94, 149, 150]. Table 3 shows the maximum adsorption capacities of chitosan nano/micro particles.

\section{Chemically Modified Chitosan for the Removal of Heavy Metal Ions}

Badawi et.al. modified the chitosan with tannic acid for the adsorption of $\mathrm{Pb}$ and aluminium (Al) ions from water [151]. Tannic acid was previously used for the removal of metal ions because of its ability to form metal complexes [46]. This research reported tannic acid with chitosan for the first time. Results concluded that maximum adsorption was achieved at $\mathrm{pH} 6$ by increasing metal ion concentration and temperature [151]. In another study [152] chitosan was modified with thiosemicarbazide (TSCS) through a condensation reaction for the removal of $\mathrm{Cu}$ (II) ions. TSCS has both sulphur and amino groups as compared to chitosan which has only an amino group. As a result, TSCS have more adsorption sites which leads to the increased removal of heavy metals. The adsorption rate however only increased up till $1.5 \mathrm{~g} / \mathrm{L}$ of TSCS concentration, beyond this point, the adsorption rate remained constant due to the limitation of free sites. In another work [153] a group of researchers studied the kinetics and adsorption isotherms for the adsorption of $\mathrm{Cu}$ (II) ions on chitin as well as pure and modified chitosan. Chitosan was chemically modified with ethylenediamine tetra-acetic acid (CS-EDTA) to eliminate copper ions from wastewater and its adsorption was compared with pure chitosan and chitin. $110 \mathrm{mg} / \mathrm{g}$ was found to be the highest 
Table 3: Maximum removal ability for heavy metal ions of chitosan nanofibers

\begin{tabular}{|c|c|c|c|c|c|}
\hline $\begin{array}{l}\text { Sr. } \\
\text { No. }\end{array}$ & Type of Adsorbent & $\begin{array}{c}\text { Adsorbate } \\
\text { Ions }\end{array}$ & $\begin{array}{c}\text { Maximum } \\
\text { Adsorption } \\
\left(q_{\max }\right) \mathrm{mg} / \mathrm{g}\end{array}$ & $\begin{array}{l}\text { Optimum pH } \\
\text { for Adsorption }\end{array}$ & Reference \\
\hline \multirow[t]{5}{*}{1} & Chitosan/PEO & $\mathrm{Ni}(\mathrm{II})$ & 175.1 & 5.5 & {$[113][114]$} \\
\hline & & $\mathrm{Cd}(\mathrm{II})$ & 143.8 & & \\
\hline & & $\mathrm{Pb}(\mathrm{II})$ & 135.4 & & \\
\hline & & $\mathrm{Cu}(\mathrm{II})$ & $163.7,106.38$ & & \\
\hline & & $\mathrm{Cr}(\mathrm{VI})$ & 136.0 & & \\
\hline \multirow[t]{2}{*}{2} & Chitosan/PVA & $\mathrm{Fe}(\mathrm{III})$ & 136 & - & {$[118]$} \\
\hline & & $\mathrm{Cu}(\mathrm{II})$ & 485.44 & & \\
\hline \multirow[t]{2}{*}{3} & Chitosan & $\mathrm{Pb}(\mathrm{II})$ & 263.15 & $2.0-3.0$ & {$[120][125]$} \\
\hline & & $\mathrm{Cr}(\mathrm{VI})$ & 68.3 & & \\
\hline \multirow[t]{3}{*}{4} & Chitosan/Graphene oxide & $\mathrm{Cu}(\mathrm{II})$ & 423.8 & $3.0 \& 6.0$ & {$[126]$} \\
\hline & & $\mathrm{Pb}(\mathrm{II})$ & 461.3 & & \\
\hline & & $\mathrm{Cr}(\mathrm{VI})$ & 310.4 & & \\
\hline \multirow[t]{3}{*}{5} & Chitosan/Hydroxyapatite & $\mathrm{Pb}(\mathrm{II})$ & 296.7 & - & {$[87]$} \\
\hline & & $\mathrm{Ni}(\mathrm{II})$ & 213.8 & & \\
\hline & & $\mathrm{Co}(\mathrm{II})$ & 180.2 & & \\
\hline \multirow[t]{2}{*}{6} & Chitosan $/ \mathrm{TiO}_{2}$ & $\mathrm{Cu}(\mathrm{II})$ & $710.3,579.1$ & 6.0 & {$[127]$} \\
\hline & & $\mathrm{Pb}(\mathrm{II})$ & $526.5,475.5$ & & \\
\hline 7 & Chitosan/polymethylmethcrylate & $\mathrm{Cr}(\mathrm{VI})$ & 92.5 & 3.0 & {$[128]$} \\
\hline
\end{tabular}

adsorption with CS-EDTA as compared to 58 and $67 \mathrm{mg} / \mathrm{g}$ for chitin and pure chitosan at pH 7 [154].

In a study, chitosan was also found to be a suitable biopolymer for the adsorption of reactive dyes from water bodies. This is due to the presence of amine and hydroxyl groups on chitosan; dyes have a strong tendency to be adsorbed at primary hydroxyl adsorption sites [155]. The temperature was found to be a major factor for the maximum adsorption of dye on chitosan; this is explained by the swelling behaviour of chitosan in previous studies. As temperature increases the internal structure of chitosan, it will swell enabling dye molecules to penetrate further [156].

In another research, the scientist made chitosan $/ \mathrm{CoFe}_{2} \mathrm{O}_{4}$ magnetic particles modified with tetraethylenepentamine (TEPA) to have maximum adsorption and magnetic properties at the same time. These particles were used for the separate adsorption of copper and lead and also with solutions that have both ions. The maximum adsorption capacity in single solutions was found to be 168 and $228 \mathrm{mg} / \mathrm{g}$ for copper and lead, while in bi-component solutions, these values were decreased to 139 and $160 \mathrm{mg} / \mathrm{g}$ with a magnetization value of $63.83 \mathrm{emu} / \mathrm{g}$ [142]. This application was lacking in preceding studies of chitosan magnetic particles where it was not possible to maintain maximum adsorption and magnetic property [93, 101, 157, 158]. However, magnetic nanoparticles are chemically active and can be easily oxidised in the air which may result in the loss of magnetism. They also cause secondary pollution in the environment due to 
Table 4: Maximum removal ability for heavy metal ions of chitosan nano/micro particles

\begin{tabular}{|c|c|c|c|c|c|}
\hline $\begin{array}{l}\text { Sr. } \\
\text { No. }\end{array}$ & Type of Adsorbent & $\begin{array}{l}\text { Adsorbate } \\
\text { Ions }\end{array}$ & $\begin{array}{l}\text { Maximum Adsorption } \\
\qquad\left(q_{\max }\right) \mathrm{mg} / \mathrm{g}\end{array}$ & $\begin{array}{l}\text { Optimum pH } \\
\text { for Adsorption }\end{array}$ & Reference \\
\hline \multirow[t]{2}{*}{1} & \multirow[t]{2}{*}{ Chitosan- $\mathrm{Fe}_{3} \mathrm{O}_{4}$} & $\mathrm{Cu}(\mathrm{II})$ & 21.5 & 5.5 & {$[135]$} \\
\hline & & $\mathrm{Co}(\mathrm{II})$ & 27.5 & & {$[136]$} \\
\hline 2 & $\alpha$-ketoglutaric acid- Chitosan & $\mathrm{Cu}(\mathrm{II})$ & 96.2 & 6.0 & {$[137]$} \\
\hline \multirow[t]{2}{*}{3} & \multirow[t]{2}{*}{ Ethylenediamine-Chitosan } & $\operatorname{Pt}(\mathrm{IV})$ & 171.0 & 2.0 & {$[138]$} \\
\hline & & $\mathrm{Pb}(\mathrm{II})$ & 138.0 & & \\
\hline \multirow[t]{2}{*}{4} & \multirow[t]{2}{*}{ Chitosan-Magnetite } & $\mathrm{Ni}(\mathrm{II})$ & 833.3 & 5.5 & {$[139]$} \\
\hline & & $\mathrm{Co}(\mathrm{II})$ & 588.2 & & \\
\hline 5 & Chitosan & $\mathrm{Pb}(\mathrm{II})$ & 398.0 & 5.5 & {$[140]$} \\
\hline \multirow[t]{2}{*}{6} & \multirow[t]{2}{*}{ Chitosan - Poly acrylic acid } & $\mathrm{Ni}(\mathrm{II})$ & 435.0 & 4.0 & {$[141]$} \\
\hline & & $\mathrm{Cu}(\mathrm{II})$ & 174.0 & & \\
\hline \multirow[t]{2}{*}{7} & \multirow[t]{2}{*}{ Chitosan-Alginate } & $\mathrm{Hg}(\mathrm{II})$ & 217.39 & 5.0 & {$[132]$} \\
\hline & & $\mathrm{Ni}(\mathrm{II})$ & 20.09 & & {$[133]$} \\
\hline \multirow[t]{2}{*}{8} & \multirow[t]{2}{*}{ Chitosan-Co $\mathrm{Fe}_{2} \mathrm{O}_{4}$} & $\mathrm{~Pb}(\mathrm{II})$ & 228.31 & 6.0 & {$[142]$} \\
\hline & & $\mathrm{Cu}(\mathrm{II})$ & 168.06 & & \\
\hline \multirow[t]{3}{*}{9} & \multirow[t]{3}{*}{ Chitosan-MAA } & $\mathrm{Pb}(\mathrm{II})$ & 11.30 & 5.0 & {$[143]$} \\
\hline & & $\mathrm{Cd}(\mathrm{II})$ & 1.84 & & \\
\hline & & $\mathrm{Ni}(\mathrm{II})$ & 0.87 & & \\
\hline \multirow[t]{2}{*}{10} & \multirow[t]{2}{*}{ Chitosan - $\mathrm{MnFe}_{2} \mathrm{O}_{4}$} & $\mathrm{Cu}(\mathrm{II})$ & 22.6 & 6.3 & {$[144]$} \\
\hline & & $\mathrm{Cr}(\mathrm{II})$ & 15.4 & & \\
\hline
\end{tabular}

their small dimensions $[159,160]$. In order to eliminate these disadvantages, magnetic chitosan composite with macro particles was developed by adding porous activated carbon for the removal of copper ions and it showed successful results with a maximum capacity for adsorption at 216.6 $/ \mathrm{mg}$ with $95 \%$ efficiency [95]. Elwakeel et al. modified magnetic chitosan with TEPA for the adsorption of uranium ions and the maximum adsorption capacity reached to $1.8 \mathrm{mmol} / \mathrm{g}$ [161].

In another study, chitosan was demonstrated as an efficient material for the removal of heavy metals from gold mining effluent. Equilibrium adsorption studies on mercury, copper, lead and zinc showed the maximum removal of these ions at higher $\mathrm{pH}$ values between 4 and 6 [169]. A. Ghee et al. comparatively studied chitosan dense and porous membranes for filtration by increasing polymer concentration and silica ratios. They found that the adsorption increased when polymer concentration is increased; this is due to the increase of amino groups. In a similar fashion, the ratio of silica increased when porosity and roughness is increased [170, 171], leading to higher surface area and more exposure to amino groups for the adsorption of copper [172]. These macroporous chitosan membranes were also used to compare adsorption of copper and nickel ion and it was found that copper ion adsorption was $19.87 \mathrm{mg} / \mathrm{g}$ which is higher than nickel (5.21 $\mathrm{mg} / \mathrm{g})[173]$.

Scientists proved that chitosan is a suitable bio sorbent for household purposes. In one study, 
Table 5: Maximum removal ability for heavy metal ions of chemically modified chitosan

\begin{tabular}{llcccc}
\hline $\begin{array}{c}\text { Sr. } \\
\text { No. }\end{array}$ & Type of Adsorbent & $\begin{array}{c}\text { Adsorbate } \\
\mathrm{Ions}\end{array}$ & $\begin{array}{c}\text { Maximum Adsorption } \\
\left(\mathrm{q}_{\max }\right) \mathrm{mg} / \mathrm{g}\end{array}$ & $\begin{array}{c}\text { Optimum } \mathrm{pH} \\
\text { for Adsorption }\end{array}$ & Reference \\
\hline 1 & Chitosan/Xanthate & $\mathrm{Pb}(\mathrm{II})$ & 76.9 & 5.0 & {$[162]$} \\
& & $\mathrm{Cu}(\mathrm{II})$ & 34.5 & & \\
& & $\mathrm{Zn}(\mathrm{II})$ & 20.8 & 5.5 & {$[163]$} \\
2 & Chitosan/Thiourea & $\mathrm{Cu}(\mathrm{II})$ & 60.6 & 4.0 & {$[164]$} \\
3 & Chitosan/EGTA & $\mathrm{Cd}(\mathrm{II})$ & 83.18 & & \\
& & $\mathrm{~Pb}(\mathrm{II})$ & 103.5 & 6.0 & {$[165]$} \\
4 & Chitosan/Activated Carbon & $\mathrm{Cd}(\mathrm{II})$ & 52.63 & $7.0-9.0$ & {$[166]$} \\
5 & Chitosan/Glycine & $\mathrm{Cu}(\mathrm{II})$ & 234.9 & & {$[167]$} \\
& & $\mathrm{Co}(\mathrm{II})$ & 281.28 & 6.0 & {$[168]$} \\
\hline
\end{tabular}

molybdate ions were successfully removed from common household contaminated groundwater. Maximum adsorption was found to be $265 \mathrm{mg} / \mathrm{g}$, which is far below bio sorbent values reported in the earlier literature [174]. (Wu et al.) and (Bertoni et al.) achieved adsorption up to 1280 $\mathrm{mg} / \mathrm{g}$ by using magnetic chitosan resin and green seaweed [175, 176]. Table 4 shows maximum adsorption capacities of modified chitosan.

\section{Coated/Porous Chitosan for the Removal of Heavy Metal Ions}

Indium (III) ions were adsorbed by using chitosan coated with bentonite beads. Research showed that using chitosan alone for the removal of heavy metals has disadvantages such as high cost and low chemical stability. So, several studies investigated to reduce above mentioned drawbacks by coating of chitosan with sand [177], calcium alginate beads [89], alumina [178], PVC beads [75] and bentonite beads. And in present study bentonite was found to be most efficient coating material for chitosan [179]. Bentonite coated chitosan displayed maximum removal percentage of indium from aqueous solution that is $99.6 \%$. Similarly it was also used in different research for adsorption of $\mathrm{Cr}(\mathrm{VI})$ and azo dye AB10B. Adsorption capacity for chromium $(66.6 \mathrm{mg} / \mathrm{g})$ and for AB10B $(847.5 \mathrm{mg} / \mathrm{g})$ respectively was reported [180].

In other application of adsorption, chitosan was coated on commercially available cotton gauze by UV radiation to remove copper and chromium ions from water solutions. Main advantages of using cotton are: it helps to limit pressure drop during continuous filament due to its open structure and it is also low cost and easily available. Research showed the optimum values for adsorption of chromium and copper at $\mathrm{pH} 3$ and 5 [181].

Porous foam of chitosan imprinted with $\mathrm{Ni}^{2+}$ was developed to improve selective adsorption of nickel from liquid solutions. This structure can provide good mechanical properties and high 
adsorption rate. In this research adsorption capacity was found to be $69.93 \mathrm{mg} / \mathrm{g}$ [182]. Recently many similar studies of chitosan porous foams have been done. Particularly chitosan/polyvinyl alcohol foam was prepared for adsorption of copper ions, which also proves to be efficient adsorbent having capacity of $193.38 \mathrm{mg} / \mathrm{g}$ for copper [96].

Another porous chitosan/graphene oxide (PGOC) was developed by unidirectional freeze drying method [183]. Graphene also has good adsorption ability and high surface area [184, 185]. Reported material showed better adsorption capability for lead ions with $31 \%$ increase due to better interaction between carboxyl groups of graphene and lead ions [186].

Table 6: Maximum removal ability for heavy metal ions of coated/porous chitosan

\begin{tabular}{|c|c|c|c|c|c|}
\hline $\begin{array}{l}\text { Sr. } \\
\text { No. }\end{array}$ & Type of Adsorbent & $\begin{array}{l}\text { Adsorbate } \\
\text { Ions }\end{array}$ & $\begin{array}{l}\text { Maximum Adsorption } \\
\qquad\left(q_{\max }\right) \mathrm{mg} / \mathrm{g}\end{array}$ & $\begin{array}{l}\text { Optimum pH } \\
\text { for Adsorption }\end{array}$ & Reference \\
\hline 1 & Chitosan/Bentonite & $\operatorname{In}(\mathrm{III})$ & 17.89 & 4.0 & {$[179]$} \\
\hline \multirow[t]{2}{*}{2} & Chitosan/Cotton Gauze & $\mathrm{Cu}(\mathrm{II})$ & 4.09 & $5.0 \& 3.0$ & {$[181]$} \\
\hline & & $\mathrm{Cr}(\mathrm{VI})$ & 1.47 & & \\
\hline \multirow[t]{3}{*}{3} & Chitosan/Resin & $\mathrm{Fe}(\mathrm{II})$ & 0.075 & - & {$[187]$} \\
\hline & & $\mathrm{Cr}(\mathrm{VI})$ & 0.038 & & \\
\hline & & $\mathrm{Pb}(\mathrm{II})$ & 0.185 & & \\
\hline 4 & Chitosan/Diatomaceous Earth & $\mathrm{Zn}(\mathrm{II})$ & 127.4 & 6.0 & {$[188]$} \\
\hline \multirow[t]{5}{*}{5} & Chitosan/Calcium Silicate & $\mathrm{Ni}(\mathrm{II})$ & 406.6 & $4.0-8.0$ & {$[189]$} \\
\hline & & $\mathrm{Zn}(\mathrm{II})$ & 400.0 & & \\
\hline & & $\mathrm{Pb}(\mathrm{II})$ & 796.0 & & \\
\hline & & $\mathrm{Cu}(\mathrm{II})$ & 578.0 & & \\
\hline & & $\mathrm{Cd}(\mathrm{II})$ & 425.0 & & \\
\hline
\end{tabular}

\section{Research Gaps and Future Recommendation}

- No studies were reported for adsorption of silver ions by using chitosan, which is a potential hazard in aqueous solutions.

- Simulation can be done of adsorption processes for accurate results and better understanding of adsorption processed.

- Chitosan coated on porous nanofibers may be used for improved adsorption of heavy metal ions due to their increased surface and area and porosity.

- Nano particles of chitosan possibly are incorporated in different polymeric structures like nano fibres, hydrogels, porous membranes, thin films for better adsorption of heavy metal ions from water. 


\section{Conclusion}

In summary, chitosan is a natural low-cost polymer with amine groups on its backbone. It is proved to be the most efficient and effective for the removal of metal pollution by the adsorption method. According to the mechanism of adsorption of heavy metals on chitosan, the $\mathrm{pH}$ of a solution is the important factor to successfully adsorb the metal ions from wastewater. However, there are other factors which significantly affect the adsorption of metal ions i.e. contact time, adsorbent dosage, temperature, concentration etc are not covered in this review. Moreover, this literature comprehensively reported and compared the adsorption capacities of crosslinked chitosan, chitosan composites, chitosan nanofibers, chitosan nanoparticles, coated chitosan and porous chitosan. Finally, the world is facing a critical issue of heavy metal pollution in wastewater, which is dangerous for both the environment and humans. Water cleaning technologies can be better understand and improved by simulating the purification processes in the future.

\section{References}

[1] N. Cartier, A. Domard, and H. Chanzy, Single crystals of chitosan, International journal of biological macromolecules, vol. 12, no. 5, 289-294, 1990.

[2] J. Boateng, Ayensu, I. and Pawar, H, Chitosan, in Mucoadhesive Materials and Drug Delivery SystemsChichester, United Kingdom.: John Wiley \& Sons, Ltd, 2014.

[3] H. H and B. M, Applications of biopolymers I: chitosan, Monatshefte für Chemie-Chemical Monthly, vol. 140, no. 12, 1403, 2009.

[4] R. A. Muzzarelli, J. Boudrant, D. Meyer, N. Manno, M. DeMarchis, and M. G. Paoletti, Current views on fungal chitin/chitosan, human chitinases, food preservation, glucans, pectins and inulin: A tribute to Henri Braconnot, precursor of the carbohydrate polymers science, on the chitin bicentennial, Carbohydrate Polymers, vol. 87, no. 2, 995-1012, 2012.

[5] J. Ruiz-Herrera, The distribution and quantitative importance of chitin in fungi, in Proceedings of the first international conference on chitin/chitosan. MIT Sea Grant Report MITSG78-7, Index, 1978, no. 78-307, 11-21.

[6] Z. M. Wu et al., Disulfide-crosslinked chitosan hydrogel for cell viability and controlled protein release, European Journal of Pharmaceutical Sciences, vol. 37, no. 3, 198-206, 2009/06/28/2009.

[7] C. Jeuniaux and M. F. Voss-Foucart, Chitin biomass and production in the marine environment, Biochemical Systematics and Ecology, vol. 19, no. 5, 347-356, 1991/08/06/1991.

[8] Y. Xu, C. Zhan, L. Fan, L. Wang, and H. Zheng, Preparation of dual crosslinked alginate chitosan blend gel beads and in vitro controlled release in oral site-specific drug delivery system, International Journal of Pharmaceutics, vol. 336, no. 2, 329-337, 2007.

[9] K. Kurita, Controlled functionalization of the polysaccharide chitin, Progress in Polymer science, vol. 26, no. 9, 1921-1971, 2001.

[10] M. Rinaudo, Chitin and chitosan: properties and applications, Progress in polymer science, vol. 31, no. 7, 603-632, 2006.

[11] A. H. Chen, S. C. Liu, C. Y. Chen, and C. Y. Chen, Comparative adsorption of Cu(II), Zn(II), and $\mathrm{Pb}(\mathrm{II})$ ions in aqueous solution on the crosslinked chitosan with epichlorohydrin, Journal of Hazardous materials, vol. 154, no. 1, 184-191, 2008.

[12] N. Gupta, A. K. Kushwaha, and M. Chattopadhyaya, Adsorptive removal of $\mathrm{Pb}^{2+}, \mathrm{Co}^{2+}$ and $\mathrm{Ni}^{2+}$ by hydroxyapatite/chitosan composite from aqueous solution, Journal of the Taiwan Institute of Chemical Engineers, vol. 43, no. 1, 125-131, 2012. 
[13] W. W. Ngah, C. Endud, and R. Mayanar, Removal of copper (II) ions from aqueous solution onto chitosan and cross-linked chitosan beads, Reactive and Functional Polymers, vol. 50, no. 2, 181-190, 2002.

[14] J. Oscik, Adsorption. Horwood, 1982.

[15] H. Stach and M. Teichmüller, Zur Chemie und Petrographie der Ionen-Austauscher aus Braun-und Steinkohlen, Brennst.-Chemie, vol. 34, 275-281, 1953.

[16] E. Guibal, C. Milot, O. Eterradossi, C. Gauffier, and A. Domard, Study of molybdate ion sorption on chitosan gel beads by different spectrometric analyses, International Journal of Biological Macromolecules, vol. 24, no. 1, 49-59, 1999.

[17] R. A. Muzzarelli, Natural chelating polymers; alginic acid, chitin and chitosan, in Natural chelating polymers; alginic acid, chitin and chitosan: Pergamon Press, 1973.

[18] R. A. Muzzarelli and R. Rocchetti, Determination of the degree of acetylation of chitosans by first derivative ultraviolet spectrophotometry, Carbohydrate Polymers, vol. 5, no. 6, 461-472, 1985.

[19] M. Rhazi, J. Desbrieres, A. Tolaimate, M. Rinaudo, P. Vottero, and A. Alagui, Contribution to the study of the complexation of copper by chitosan and oligomers, Polymer, vol. 43, no. 4, 1267-1276, 2002.

[20] R. Muzzarelli and M. Peter, Chitin Handbook, European Chitin Society, TAPPI (2000-2001): Test Methods. T, vol. 491, 1997.

[21] M. Rhazi et al., Influence of the nature of the metal ions on the complexation with chitosan.: Application to the treatment of liquid waste, European Polymer Journal, vol. 38, no. 8, 15231530, 2002.

[22] G. Micera, S. Deiana, A. Dessi, P. Decock, B. Dubois, and H. Kozowski, Copper (II) complexation by D-glucosamine. Spectroscopic and potentiometric studies, Inorganica chimica acta, vol. 107, no. $1,45-48,1985$.

[23] T. S. Keisuke Kurita, and Yoshio Iwakura, Evidence for Formation of Block and Random Copolymers of N-Acetyl-D-glucosamine and D-Giucosamine by Hetero- and Homogeneous Hydrolyses, Makromol. Chem., vol. 178, 3197-3202, April 18, 19771977.

[24] F. C. Barros et al., Removal of Copper, Nickel and Zinc Ions from Aqueous Solution by Chitosan8-Hydroxyquinoline Beads, Clean-Soil, Air, Water, vol. 36, no. 3, 292-298, 2008.

[25] V. M. Boddu, K. Abburi, A. J. Randolph, and E. D. Smith, Removal of copper (II) and nickel (II) ions from aqueous solutions by a composite chitosan biosorbent, Separation science and technology, vol. 43, no. 6, 1365-1381, 2008.

[26] T. Gotoh, K. Matsushima, and K. I. Kikuchi, Preparation of alginate-chitosan hybrid gel beads and adsorption of divalent metal ions, Chemosphere, vol. 55, no. 1, 135-140, 2004.

[27] S. K. Papageorgiou, F. K. Katsaros, E. P. Kouvelos, and N. K. Kanellopoulos, Prediction of binary adsorption isotherms of $\mathrm{Cu}^{2+}, \mathrm{Cd}^{2+}$ and $\mathrm{Pb}^{2+}$ on calcium alginate beads from single adsorption data, Journal of Hazardous Materials, vol. 162, no. 2, 1347-1354, 2009/03/15/ 2009.

[28] L. Fan, C. Luo, Z. Lv, F. Lu, and H. Qiu, Preparation of magnetic modified chitosan and adsorption of $\mathrm{Zn}^{2+}$ from aqueous solutions, Colloids and Surfaces B: Biointerfaces, vol. 88, no. 2, 574-581, 2011.

[29] L. Fan, C. Luo, Z. Lv, F. Lu, and H. Qiu, Removal of $\mathrm{Ag}^{+}$from water environment using a novel magnetic thiourea-chitosan imprinted $\mathrm{Ag}^{+}$, Journal of hazardous materials, vol. 194, 193-201, 2011.

[30] J. f. Liu, Z. S. Zhao, and G. B. Jiang, Coating $\mathrm{Fe}_{3} \mathrm{O}_{4}$ magnetic nanoparticles with humic acid for high efficient removal of heavy metals in water, Environmental science \& technology, vol. 42, no. 18, 6949-6954, 2008. 
[31] M. Tabakci and M. Yilmaz, Synthesis of a chitosan-linked calix [4] arene chelating polymer and its sorption ability toward heavy metals and dichromate anions, Bioresource technology, vol. 99, no. 14, 6642-6645, 2008.

[32] I. S. Butler, H. A. M. El-Sherbeny, I. Kenawy, and S. I. Mostafa, Cellulose derivatives modified by sodium tellurate and a chromium (III) tellurate complex, International journal of biological macromolecules, vol. 88, 392-402, 2016.

[33] V. Gupta, S. Agarwal, and T. A. Saleh, Chromium removal by combining the magnetic properties of iron oxide with adsorption properties of carbon nanotubes, Water research, vol. 45, no. 6, 2207-2212, 2011.

[34] Y. Ho and G. McKay, Sorption of copper (II) from aqueous solution by peat, Water, Air, \& Soil Pollution, vol. 158, no. 1, 77-97, 2004.

[35] B. Kannamba, K. L. Reddy, and B. AppaRao, Removal of $\mathrm{Cu}(\mathrm{II})$ from aqueous solutions using chemically modified chitosan, Journal of Hazardous Materials, vol. 175, no. 1, 939-948, 2010.

[36] F. C. Wu, R. L. Tseng, and R. S. Juang, A review and experimental verification of using chitosan and its derivatives as adsorbents for selected heavy metals, Journal of Environmental Management, vol. 91, no. 4, 798-806, 2010.

[37] O. M. M. Freitas, R. J. E. Martins, C. M. Delerue-Matos, and R. A. R. Boaventura, Removal of $\mathrm{Cd}(\mathrm{II}), \mathrm{Zn}(\mathrm{II})$ and $\mathrm{Pb}(\mathrm{II})$ from aqueous solutions by brown marine macro algae: Kinetic modelling, Journal of Hazardous Materials, vol. 153, no. 1, 493-501, 2008/05/01/2008.

[38] A. Heidari, H. Younesi, and Z. Mehraban, Removal of $\mathrm{Ni}(\mathrm{II}), \mathrm{Cd}(\mathrm{II})$, and $\mathrm{Pb}$ (II) from a ternary aqueous solution by amino functionalized mesoporous and nano mesoporous silica, Chemical Engineering Journal, vol. 153, no. 1, 70-79, 2009.

[39] A. T. Paulino, L. B. Santos, and J. Nozaki, Removal of $\mathrm{Pb}^{2+}, \mathrm{Cu}^{2+}$, and $\mathrm{Fe}^{3+}$ from battery manufacture wastewater by chitosan produced from silkworm chrysalides as a low-cost adsorbent, Reactive and functional polymers, vol. 68, no. 2, 634-642, 2008.

[40] A. Sari, D. Mendil, M. Tuzen, and M. Soylak, Biosorption of Cd(II) and Cr(III) from aqueous solution by moss (Hylocomium splendens) biomass: equilibrium, kinetic and thermodynamic studies, Chemical Engineering Journal, vol. 144, no. 1, 1-9, 2008.

[41] S. Hajialigol, M. Taher, and A. Malekpour, A new method for the selective removal of cadmium and zinc ions from aqueous solution by modified clinoptilolite, Adsorption Science \& Technology, vol. 24 , no. 6, 487-496, 2006.

[42] M. Ghaedi, Selective and sensitized spectrophotometric determination of trace amounts of Ni(II) ion using $\alpha$-benzyl dioxime in surfactant media, Spectrochimica Acta Part A: Molecular and Biomolecular Spectroscopy, vol. 66, no. 2, 295-301, 2007.

[43] M. Soylak, A. Kars, and I. Narin, Coprecipitation of $\mathrm{Ni}^{2+}, \mathrm{Cd}^{2+}$ and $\mathrm{Pb}^{2+}$ for preconcentration in environmental samples prior to flame atomic absorption spectrometric determinations, Journal of hazardous materials, vol. 159, no. 2, 435-439, 2008.

[44] N. Toxicology, carcinogenesis studies of sodium dichromate dihydrate (CAS No. 7789-12-0) in F344/N rats and B6C3F1 mice (drinking water studies), Natl Toxicol Program Tech Rep Ser, vol. 546, 1-192, 2008.

[45] Z. A. Al-Othman, R. Ali, and M. Naushad, Hexavalent chromium removal from aqueous medium by activated carbon prepared from peanut shell: adsorption kinetics, equilibrium and thermodynamic studies, Chemical Engineering Journal, vol. 184, 238-247, 2012.

[46] W. Li, X. Gong, X. Li, D. Zhang, and H. Gong, Removal of Cr(VI) from low-temperature micropolluted surface water by tannic acid immobilized powdered activated carbon, Bioresource technology, vol. 113, 106-113, 2012. 
[47] T. Anirudhan, J. Nima, and P. Divya, Adsorption of chromium (VI) from aqueous solutions by glycidylmethacrylate-grafted-densified cellulose with quaternary ammonium groups, Applied Surface Science, vol. 279, 441-449, 2013.

[48] A. Chiu, A. Katz, J. Beaubier, N. Chiu, and X. Shi, Genetic and cellular mechanisms in chromium and nickel carcinogenesis considering epidemiologic findings, Molecular and cellular biochemistry, vol. 255, no. 1, 181-194, 2004.

[49] L. Li, Y. Li, L. Cao, and C. Yang, Enhanced chromium (VI) adsorption using nanosized chitosan fibers tailored by electrospinning, Carbohydr Polym, vol. 125, 206-13, Jul 102015.

[50] M. Gueye, Y. Richardson, F. T. Kafack, and J. Blin, High efficiency activated carbons from African biomass residues for the removal of chromium (VI) from wastewater, Journal of Environmental Chemical Engineering, vol. 2, no. 1, 273-281, 2014.

[51] K. Y. Kumar, H. Muralidhara, Y. A. Nayaka, J. Balasubramanyam, and H. Hanumanthappa, Low-cost synthesis of metal oxide nanoparticles and their application in adsorption of commercial dye and heavy metal ion in aqueous solution, Powder technology, vol. 246, 125-136, 2013.

[52] A. Murugesan, T. Vidhyadevi, S. D. Kirupha, L. Ravikumar, and S. Sivanesan, Removal of chromium (VI) from aqueous solution using chemically modified corncorb-activated carbon: Equilibrium and kinetic studies, Environmental Progress \& Sustainable Energy, vol. 32, no. 3, 673-680, 2013.

[53] Q. Q. Zhong, Q. Y. Yue, Q. Li, B. Y. Gao, and X. Xu, Removal of $\mathrm{Cu}(\mathrm{II})$ and $\mathrm{Cr}(\mathrm{VI})$ from wastewater by an amphoteric sorbent based on cellulose-rich biomass, Carbohydrate polymers, vol. 111, 788-796, 2014.

[54] D. Bhowmik and K. Chiranjib, A potential medicinal importance of zinc in human health and chronic, Int J Pharm, vol. 1, no. 1, 05-11, 2010.

[55] D. J. Ennigrou, M. B. S. Ali, and M. Dhahbi, Copper and Zinc removal from aqueous solutions by polyacrylic acid assisted-ultrafiltration, Desalination, vol. 343, 82-87, 2014.

[56] D. J. Ennigrou, L. Gzara, M. R. B. Romdhane, and M. Dhahbi, Retention of cadmium ions from aqueous solutions by poly (ammonium acrylate) enhanced ultrafiltration, Chemical Engineering Journal, vol. 155, no. 1, 138-143, 2009.

[57] J. Godt et al., The toxicity of cadmium and resulting hazards for human health, Journal of occupational medicine and toxicology, vol. 1, no. 1, p. 22, 2006.

[58] F. Bakir et al., Methylmercury poisoning in Iraq, Science, vol. 181, no. 4096, 230-241, 1973.

[59] R. A. Bernhoft, Mercury toxicity and treatment: a review of the literature, Journal of environmental and public health, vol. 2012, 2011.

[60] T. Clarkson et al., Tests of efficacy of antidotes for removal of methylmercury in human poisoning during the Iraq outbreak, Journal of Pharmacology and Experimental Therapeutics, vol. 218, no. 1, 74-83, 1981.

[61] S. B. Skerfving and J. Copplestone, Poisoning caused by the consumption of organomercurydressed seed in Iraq, Bulletin of the World Health Organization, vol. 54, no. 1, 101, 1976.

[62] R. Bhatt, B. Sreedhar, and P. Padmaja, Adsorption of chromium from aqueous solutions using crosslinked chitosan-diethylenetriaminepentaacetic acid, Int J Biol Macromol, vol. 74, 458-66, Mar 2015.

[63] R. Bhatt, B. Sreedhar, and P. Padmaja, Chitosan supramolecularly cross linked with trimesic acid - Facile synthesis, characterization and evaluation of adsorption potential for chromium(VI), Int J Biol Macromol, vol. 104, no. Pt A, 1254-1266, Nov 2017.

[64] Z. Abdeen, S. G. Mohammad, and M. S. Mahmoud, Adsorption of Mn(II) ion on polyvinyl alcohol/chitosan dry blending from aqueous solution, Environmental Nanotechnology, Monitoring \& Management, vol. 3, 1-9, 2015. 
[65] A. I. Adeogun, M. A. Idowu, A. E. Ofudje, S. O. Kareem, and S. A. Ahmed, Comparative biosorption of $\mathrm{Mn}(\mathrm{II})$ and $\mathrm{Pb}(\mathrm{II})$ ions on raw and oxalic acid modified maize husk: kinetic, thermodynamic and isothermal studies, Applied Water Science, vol. 3, no. 1, 167-179, 2012.

[66] A. H. Chen, S. C. Liu, C. Y. Chen, and C. Y. Chen, Comparative adsorption of Cu(II), Zn(II), and $\mathrm{Pb}(\mathrm{II})$ ions in aqueous solution on the crosslinked chitosan with epichlorohydrin, J Hazard Mater, vol. 154, no. 1-3, 184-91, Jun 152008.

[67] W. S. W. Ngah, C. S. Endud, and R. Mayanar, Removal of copper (II) ions from aqueous solution onto chitosan and cross-linked chitosan beads, Reactive \& Functional Polymer, vol. 50, 181-190, 2002.

[68] A. H. Chen, C. Y. Yang, C. Y. Chen, C. Y. Chen, and C. W. Chen, The chemically crosslinked metal-complexed chitosans for comparative adsorptions of $\mathrm{Cu}(\mathrm{II}), \mathrm{Zn}$ (II), $\mathrm{Ni}(\mathrm{II})$ and $\mathrm{Pb}$ (II) ions in aqueous medium, J Hazard Mater, vol. 163, no. 2-3, 1068-75, Apr 302009.

[69] V. N. Tirtom, A. Dinçer, S. Becerik, T. Aydemir, and A. Çelik, Comparative adsorption of Ni(II) and $\mathrm{Cd}(\mathrm{II})$ ions on epichlorohydrin crosslinked chitosan-clay composite beads in aqueous solution, Chemical Engineering Journal, vol. 197, 379-386, 2012.

[70] M. Kumar, B. P. Tripathi, and V. K. Shahi, Crosslinked chitosan/polyvinyl alcohol blend beads for removal and recovery of $\mathrm{Cd}(\mathrm{II})$ from wastewater, Journal of Hazardous Materials, vol. 172, no. 2, 1041-1048, 2009/12/30/ 2009.

[71] T. Shi, D. Yang, H. Yang, J. Ye, and Q. Cheng, Preparation of chitosan crosslinked modified silicon material and its adsorption capability for chromium (VI), Applied Clay Science, vol. 142, 100-108, 2017.

[72] Manasi, V. Rajesh, and N. Rajesh, An indigenous Halomonas BVR1 strain immobilized in crosslinked chitosan for adsorption of lead and cadmium, Int J Biol Macromol, vol. 79, 300-8, Aug 2015.

[73] K. R. Krishnapriya and M. Kandaswamy, Synthesis and characterization of a crosslinked chitosan derivative with a complexing agent and its adsorption studies toward metal (II) ions, Carbohydr Res, vol. 344, no. 13, 1632-8, Sep 082009.

[74] M. E. A. Ali, Synthesis and adsorption properties of chitosan-CDTA-GO nanocomposite for removal of hexavalent chromium from aqueous solutions, Arabian Journal of Chemistry, 2016.

[75] V. M. Boddu, Krishnaiah Abburi, A. JONATHAN L. TALBOTT, and E. D. SMITH, Removal of Hexavalent Chromium from Wastewater Using a New Composite Chitosan Biosorbent, Environmental Science \& Technology, vol. 37, 4449-4456, 2003.

[76] H. T. Kahraman, Development of an adsorbent via chitosan nano-organoclay assembly to remove hexavalent chromium from wastewater, Int J Biol Macromol, vol. 94, no. Pt A, 202-209, Jan 2017.

[77] C. Shao, H. Y. Kim, J. Gong, B. Ding, D. R. Lee, and S. J. Park, Fiber mats of poly(vinyl alcohol)/silica composite via electrospinning, Materials Letters, vol. 57, no. 9, 1579-1584, 2003/02/01/2003.

[78] U. Habiba, T. C. Joo, T. A. Siddique, A. Salleh, B. C. Ang, and A. M. Afifi, Effect of degree of deacetylation of chitosan on adsorption capacity and reusability of chitosan/polyvinyl alcohol/ $\mathrm{TiO}_{2}$ nano composite, Int J Biol Macromol, vol. 104, no. Pt A, 1133-1142, Nov 2017.

[79] C. $\mathrm{Hu}, \mathrm{P} . \mathrm{Zhu}, \mathrm{M}$. Cai, H. Hu, and Q. Fu, Comparative adsorption of $\mathrm{Pb}(\mathrm{II}), \mathrm{Cu}(\mathrm{II})$ and $\mathrm{Cd}(\mathrm{II})$ on chitosan saturated montmorillonite: Kinetic, thermodynamic and equilibrium studies, Applied Clay Science, vol. 143, 320-326, 2017.

[80] H. He, L. Ma, J. Zhu, R. L. Frost, B. K. G. Theng, and F. Bergaya, Synthesis of organoclays: A critical review and some unresolved issues, Applied Clay Science, vol. 100, no. Supplement C, 22-28, 2014/10/01/ 2014.

[81] J. M. Brady and J. M. Tobin, Binding of hard and soft metal ions to Rhizopus arrhizus biomass, Enzyme and Microbial Technology, vol. 17, no. 9, 791-796, 1995/09/01/ 1995. 
[82] C. M. Futalan, C. C. Kan, M. L. Dalida, K. J. Hsien, C. Pascua, and M. W. Wan, Comparative and competitive adsorption of copper, lead, and nickel using chitosan immobilized on bentonite, Carbohydrate Polymers, vol. 83, no. 2, 528-536, 2011/01/10/ 2011.

[83] D. Soltermann, M. Marques Fernandes, B. Baeyens, J. Miehé-Brendlé and R. Dähn, Competitive Fe(II)-Zn(II) Uptake on a Synthetic Montmorillonite, Environmental Science \& Technology, vol. 48, no. 1, 190-198, 2014/01/07 2014.

[84] K. Vijayaraghavan, T. T. Teo, R. Balasubramanian, and U. M. Joshi, Application of Sargassum biomass to remove heavy metal ions from synthetic multi-metal solutions and urban storm water runoff, Journal of Hazardous Materials, vol. 164, no. 2, 1019-1023, 2009/05/30/ 2009.

[85] D. Ramimoghadam, S. Bagheri, and S. B. A. Hamid, Progress in electrochemical synthesis of magnetic iron oxide nanoparticles, Journal of Magnetism and Magnetic Materials, vol. 368, no. Supplement C, 207-229, 2014/11/01/ 2014.

[86] H. Karaer and I Kaya, Synthesis, characterization and using at the copper adsorption of chitosan/polyvinyl alcohol magnetic composite, Journal of Molecular Liquids, vol. 230, 152-162, 2017.

[87] M. Aliabadi, M. Irani, J. Ismaeili, and S. Najafzadeh, Design and evaluation of chitosan/hydroxyapatite composite nanofiber membrane for the removal of heavy metal ions from aqueous solution, Journal of the Taiwan Institute of Chemical Engineers, vol. 45, no. 2, 518-526, 2014/03/01/ 2014.

[88] M. V. Dinu and E. S. Dragan, Evaluation of $\mathrm{Cu}^{2+}, \mathrm{Co}^{2+}$ and $\mathrm{Ni}^{2+}$ ions removal from aqueous solution using a novel chitosan/clinoptilolite composite: Kinetics and isotherms, Chemical Engineering Journal, vol. 160, no. 1, 157-163, 2010/05/15/2010.

[89] Y. Vijaya, S. R. Popuri, V. M. Boddu, and A. Krishnaiah, Modified chitosan and calcium alginate biopolymer sorbents for removal of nickel (II) through adsorption, Carbohydrate polymers, vol. 72, no. 2, 261-271, 2008.

[90] G. N. Kousalya, M. Rajiv Gandhi, C. Sairam Sundaram, and S. Meenakshi, Synthesis of nanohydroxyapatite chitin/chitosan hybrid biocomposites for the removal of Fe(III), Carbohydrate Polymers, vol. 82, no. 3, 594-599, 2010.

[91] E. M. Azzam et al., Preparation and characterization of chitosan-clay nanocomposites for the removal of $\mathrm{Cu}$ (II) from aqueous solution, Int J Biol Macromol, vol. 89, 507-17, Aug 2016.

[92] V. M. Boddu, K. Abburi, J. L. Talbott, E. D. Smith, and R. Haasch, Removal of arsenic (III) and arsenic (V) from aqueous medium using chitosan-coated biosorbent, Water research, vol. 42, no. 3, 633-642, 2008.

[93] L. Fan, C. Luo, M. Sun, X. Li, and H. Qiu, Highly selective adsorption of lead ions by waterdispersible magnetic chitosan/graphene oxide composites, Colloids Surf B Biointerfaces, vol. 103, 523-9, Mar 012013.

[94] X. Guo et al., Synthesis of amino functionalized magnetic graphenes composite material and its application to remove $\mathrm{Cr}(\mathrm{VI}), \mathrm{Pb}(\mathrm{II}), \mathrm{Hg}(\mathrm{II}), \mathrm{Cd}(\mathrm{II})$ and $\mathrm{Ni}(\mathrm{II})$ from contaminated water, $\mathrm{J}$ Hazard Mater, vol. 278, 211-20, Aug 152014.

[95] J. Li et al., Preparation and adsorption properties of magnetic chitosan composite adsorbent for $\mathrm{Cu} 2+$ removal, Journal of Cleaner Production, vol. 158, 51-58, 2017.

[96] X. Li, Y. Li, S. Zhang, and Z. Ye, Preparation and characterization of new foam adsorbents of poly(vinyl alcohol)/chitosan composites and their removal for dye and heavy metal from aqueous solution, Chemical Engineering Journal, vol. 183, 88-97, 2012.

[97] X. Li, H. Zhou, W. Wu, S. Wei, Y. Xu, and Y. Kuang, Studies of heavy metal ion adsorption on chitosan/sulfydryl-functionalized graphene oxide composites, J Colloid Interface Sci, vol. 448, 389-97, Jun 152015.

[98] T. Liu et al., Magnetic chitosan/anaerobic granular sludge composite: Synthesis, characterization and application in heavy metal ions removal, J Colloid Interface Sci, vol. 508, 405-414, Dec 15 2017. 
[99] A. P et al., Removal of toxic heavy metal lead (II) using chitosan oligosaccharide-graft-maleic anhydride/polyvinyl alcohol/silk fibroin composite, Int J Biol Macromol, vol. 104, no. Pt B, 14691482, Nov 2017.

[100] S. Saber-Samandari, S. Saber-Samandari, N. Nezafati, and K. Yahya, Efficient removal of lead (II) ions and methylene blue from aqueous solution using chitosan/Fe-hydroxyapatite nanocomposite beads, J Environ Manage, vol. 146, 481-490, Dec 152014.

[101] H. V. Tran, L. D. Tran, and T. N. Nguyen, Preparation of chitosan/magnetite composite beads and their application for removal of $\mathrm{Pb}$ (II) and $\mathrm{Ni}(\mathrm{II})$ from aqueous solution, Materials Science and Engineering: C, vol. 30, no. 2, 304-310, 2010.

[102] S. Hasan, T. K. Ghosh, D. S. Viswanath, and V. M. Boddu, Dispersion of chitosan on perlite for enhancement of copper (II) adsorption capacity, Journal of Hazardous Materials, vol. 152, no. 2, 826-837, 2008.

[103] S. Hasan, A. Krishnaiah, T. K. Ghosh, D. S. Viswanath, V. M. Boddu, and E. D. Smith, Adsorption of Chromium (VI) on Chitosan-Coated Perlite, Separation science and technology, vol. 38, no. 15, 3775-3793, 2003.

[104] S. Hasan, A. Krishnaiah, T. K. Ghosh, D. S. Viswanath, V. M. Boddu, and E. D. Smith, Adsorption of divalent cadmium $(\mathrm{Cd}(\mathrm{II})$ ) from aqueous solutions onto chitosan-coated perlite beads, Industrial \& engineering chemistry research, vol. 45, no. 14, 5066-5077, 2006.

[105] S. Kalyani, J. A. Priya, P. S. Rao, and A. Krishnaiah, Removal of Copper and Nickel from Aqueous Solutions Using Chitosan Coated on Perlite as Biosorbent, Separation Science and Technology, vol. 40, no. 7, 1483-1495, 2005/05/01 2005.

[106] S. R. Popuri, Y. Vijaya, V. M. Boddu, and K. Abburi, Adsorptive removal of copper and nickel ions from water using chitosan coated PVC beads, Bioresource technology, vol. 100, no. 1, 194-199, 2009.

[107] W. W. Ngah, L. Teong, and M. Hanafiah, Adsorption of dyes and heavy metal ions by chitosan composites: A review, Carbohydrate polymers, vol. 83, no. 4, 1446-1456, 2011.

[108] D. Fan, X. Zhu, M. Xu, and J. Yan, Adsorption properties of chromium (VI) by chitosan coated montmorillonite, Journal of Biological Sciences, vol. 6, no. 5, 941-945, 2006.

[109] W. W. Ngah and S. Fatinathan, Adsorption of $\mathrm{Cu}(\mathrm{II})$ ions in aqueous solution using chitosan beads, chitosan-GLA beads and chitosan-alginate beads, Chemical Engineering Journal, vol. 143, no. 1, 62-72, 2008.

[110] D. Humelnicu, M. V. Dinu, and E. S. Dragan, Adsorption characteristics of UO $(2)(2+)$ and $\operatorname{Th}(4+)$ ions from simulated radioactive solutions onto chitosan/clinoptilolite sorbents, J Hazard Mater, vol. 185, no. 1, 447-55, Jan 152011.

[111] E. S. D. M. V. Dinu, Removal of copper ions from aqueous solution by adsorption on ionic hybrids based on chitosan and clinoptilolite, Ion exchange Letters, vol. 2, 15-18, 2009.

[112] E. S. Dragan, M. V. Dinu, and D. Timpu, Preparation and characterization of novel composites based on chitosan and clinoptilolite with enhanced adsorption properties for $\mathrm{Cu}^{2+}$, Bioresource Technology, vol. 101, no. 2, 812-817, 2010/01/01/ 2010.

[113] M. Aliabadi, M. Irani, J. Ismaeili, H. Piri, and M. J. Parnian, Electrospun nanofiber membrane of PEO/Chitosan for the adsorption of nickel, cadmium, lead and copper ions from aqueous solution, Chemical Engineering Journal, vol. 220, 237-243, 2013.

[114] I. Lakhdhar, P. Mangin, and B. Chabot, Copper (II) ions adsorption from aqueous solutions using electrospun chitosan/peo nanofibres: Effects of process variables and process optimization, Journal of Water Process Engineering, vol. 7, 295-305, 2015.

[115] A. Esmaeili and A. A. Beni, A novel fixed-bed reactor design incorporating an electrospun PVA/chitosan nanofiber membrane, Journal of Hazardous Materials, vol. 280, no. Supplement C, 788-796, 2014/09/15/ 2014. 
[116] U. Habiba, A. M. Afifi, A. Salleh, and B. C. Ang, Chitosan/(polyvinyl alcohol)/zeolite electrospun composite nanofibrous membrane for adsorption of $\mathrm{Cr}^{6+}, \mathrm{Fe}^{3+}$ and $\mathrm{Ni2}$, J Hazard Mater, vol. 322, no. Pt A, 182-194, Jan 152017.

[117] R. Shannon, Revised effective ionic radii and systematic studies of interatomic distances in halides and chalcogenides, Acta Crystallographica Section A, vol. 32, no. 5, 751-767, 1976.

[118] U. Habiba et al., Effect of deacetylation on property of electrospun chitosan/PVA nanofibrous membrane and removal of methyl orange, $\mathrm{Fe}(\mathrm{III})$ and $\mathrm{Cr}(\mathrm{VI})$ ions, Carbohydr Polym, vol. 177, 32-39, Dec 012017.

[119] H. Zhang et al., Adsorption of iodide ions on a calcium alginate-silver chloride composite adsorbent, Colloids and Surfaces A: Physicochemical and Engineering Aspects, vol. 386, no. 1, 166-171, 2011/08/05/ 2011.

[120] S. Haider and S. Y. Park, Preparation of the electrospun chitosan nanofibers and their applications to the adsorption of $\mathrm{Cu}(\mathrm{II})$ and $\mathrm{Pb}(\mathrm{II})$ ions from an aqueous solution, Journal of Membrane Science, vol. 328, no. 1-2, 90-96, 2009.

[121] R. Bassi, S. O. Prasher, and B. K. Simpson, Removal of Selected Metal Ions from Aqueous Solutions Using Chitosan Flakes, Separation Science and Technology, vol. 35, no. 4, 547-560, 2000/01/04 2000.

[122] C. Huang, Y. C. Chung, and M. R. Liou, Adsorption of $\mathrm{Cu}(\mathrm{II})$ and $\mathrm{Ni}(\mathrm{II})$ by pelletized biopolymer, Journal of Hazardous Materials, vol. 45, no. 2, 265-277, 1996/02/01/ 1996.

[123] H. L. Vasconcelos, V. T. Fávere, N. S. Gonçalves, and M. C. M. Laranjeira, Chitosan modified with Reactive Blue 2 dye on adsorption equilibrium of $\mathrm{Cu}(\mathrm{II})$ and $\mathrm{Ni}(\mathrm{II})$ ions, Reactive and Functional Polymers, vol. 67, no. 10, 1052-1060, 2007/10/01/ 2007.

[124] W. S. Wan Ngah, C. S. Endud, and R. Mayanar, Removal of copper(II) ions from aqueous solution onto chitosan and cross-linked chitosan beads, Reactive and Functional Polymers, vol. 50, no. 2, 181-190, 2002/01/01/ 2002.

[125] L. Li, Y. Li, L. Cao, and C. Yang, Enhanced chromium (VI) adsorption using nanosized chitosan fibers tailored by electrospinning, Carbohydrate Polymers, vol. 125, no. Supplement C, 206-213, 2015/07/10/ 2015.

[126] H. Hadi Najafabadi, M. Irani, L. Roshanfekr Rad, A. Heydari Haratameh, and I. Haririan, Removal of $\mathrm{Cu}^{2+}, \mathrm{Pb}^{2+}$ and $\mathrm{Cr}^{6+}$ from aqueous solutions using a chitosan/graphene oxide composite nanofibrous adsorbent, RSC Advances, vol. 5, no. 21, 16532-16539, 2015.

[127] A. Razzaz, S. Ghorban, L. Hosayni, M. Irani, and M. Aliabadi, Chitosan nanofibers functionalized by $\mathrm{TiO}_{2}$ nanoparticles for the removal of heavy metal ions, Journal of the Taiwan Institute of Chemical Engineers, vol. 58, 333-343, 2016.

[128] Z. Li, T. Li, L. An, P. Fu, C. Gao, and Z. Zhang, Highly efficient chromium (VI) adsorption with nanofibrous filter paper prepared through electrospinning chitosan/polymethylmethacrylate composite, Carbohydr Polym, vol. 137, 119-126, Feb 102016.

[129] W. B. Wang, D. J. Huang, Y. R. Kang, and A. Q. Wang, One-step in situ fabrication of a granular semi-IPN hydrogel based on chitosan and gelatin for fast and efficient adsorption of $\mathrm{Cu}^{2+}$ ion, Colloids Surf B Biointerfaces, vol. 106, 51-9, Jun 01, 2013.

[130] S. Gokila, T. Gomathi, P. N. Sudha, and S. Anil, Removal of the heavy metal ion chromiuim (VI) using Chitosan and Alginate nanocomposites, Int J Biol Macromol, vol. 104, no. Pt B, 1459-1468, Nov 2017.

[131] V. K. Gupta et al., Fabrication of chitosan-g-poly(acrylamide)/Cu nanocomposite for the removal of $\mathrm{Pb}(\mathrm{II})$ from aqueous solutions, Journal of Molecular Liquids, vol. 224, 1319-1325, 2016.

[132] R. Dubey, J. Bajpai, and A. K. Bajpai, Chitosan-alginate nanoparticles (CANPs) as potential nanosorbent for removal of $\mathrm{Hg}$ (II) ions, Environmental Nanotechnology, Monitoring \& Management, vol. 6, 32-44, 2016. 
[133] A. Esmaeili and N. Khoshnevisan, Optimization of process parameters for removal of heavy metals by biomass of $\mathrm{Cu}$ and $\mathrm{Co}$-doped alginate-coated chitosan nanoparticles, Bioresour Technol, vol. $218,650-8$, Oct 2016.

[134] C. Hua, R. Zhang, F. Bai, P. Lu, and X. Liang, Removal of chromium (VI) from aqueous solutions using quaternized chitosan microspheres, Chinese Journal of Chemical Engineering, vol. 25, no. 2, 153-158, 2017.

[135] Y. C. Chang and D.H. Chen, Preparation and adsorption properties of monodisperse chitosanbound $\mathrm{Fe}_{3} \mathrm{O}_{4}$ magnetic nanoparticles for removal of $\mathrm{Cu}(\mathrm{II})$ ions, Journal of Colloid and Interface Science, vol. 283, no. 2, 446-451, 2005.

[136] Y. C. Chang, S. W. Chang, and D. H. Chen, Magnetic chitosan nanoparticles: Studies on chitosan binding and adsorption of Co(II) ions, Reactive and Functional Polymers, vol. 66, no. 3, 335-341, 2006.

[137] Y. T. Zhou, H. L. Nie, C. Branford-White, Z. Y. He, and L. M. Zhu, Removal of $\mathrm{Cu}^{2+}$ from aqueous solution by chitosan-coated magnetic nanoparticles modified with $\alpha$-ketoglutaric acid, Journal of Colloid and Interface Science, vol. 330, no. 1, 29-37, 2009.

[138] L. Zhou, J. Xu, X. Liang, and Z. Liu, Adsorption of platinum (IV) and palladium (II) from aqueous solution by magnetic cross-linking chitosan nanoparticles modified with ethylenediamine, Journal of Hazardous Materials, vol. 182, no. 1, 518-524, 2010.

[139] D. Hritcu, G. Dodi, and M. I. Popa, Heavy metal ions adsorption on chitosan-magnetite microspheres, International Review of Chemical Engineering, vol. 4, no. 3, 364-368, 2012.

[140] L. Qi and Z. Xu, Lead sorption from aqueous solutions on chitosan nanoparticles, Colloids and Surfaces A: Physicochemical and Engineering Aspects, vol. 251, no. 1, 183-190, 2004.

[141] H. Yan, L. Yang, Z. Yang, H. Yang, A. Li, and R. Cheng, Preparation of chitosan/poly(acrylic acid) magnetic composite microspheres and applications in the removal of copper (II) ions from aqueous solutions, Journal of hazardous materials, vol. 229, 371-380, 2012.

[142] C. Fan, K. Li, J. Li, D. Ying, Y. Wang, and J. Jia, Comparative and competitive adsorption of $\mathrm{Pb}(\mathrm{II})$ and $\mathrm{Cu}(\mathrm{II})$ using tetraethylenepentamine modified chitosan/CoFe2O4 particles, J Hazard Mater, vol. 326, 211-220, Mar 152017.

[143] A. Heidari, H. Younesi, Z. Mehraban, and H. Heikkinen, Selective adsorption of Pb(II), Cd(II), and $\mathrm{Ni}(\mathrm{II})$ ions from aqueous solution using chitosan-MAA nanoparticles, Int J Biol Macromol, vol. 61, 251-63, Oct 2013.

[144] Y. Xiao, H. Liang, W. Chen, and Z. Wang, Synthesis and adsorption behavior of chitosan-coated $\mathrm{MnFe}_{2} \mathrm{O}_{4}$ nanoparticles for trace heavy metal ions removal, Applied Surface Science, vol. 285, 498-504, 2013.

[145] H. L. Fan, S. F. Zhou, W. Z. Jiao, G. S. Qi, and Y. Z. Liu, Removal of heavy metal ions by magnetic chitosan nanoparticles prepared continuously via high-gravity reactive precipitation method, Carbohydr Polym, vol. 174, 1192-1200, Oct 15, 2017.

[146] A. Z. Badruddoza, Z. B. Shawon, W. J. Tay, K. Hidajat, and M. S. Uddin, $\mathrm{Fe}_{3} \mathrm{O}_{4} /$ cyclodextrin polymer nanocomposites for selective heavy metals removal from industrial wastewater, Carbohydr Polym, vol. 91, no. 1, 322-32, Jan 02, 2013.

[147] M. A. Barakat and R. Kumar, Synthesis and characterization of porous magnetic silica composite for the removal of heavy metals from aqueous solution, Journal of Industrial and Engineering Chemistry, vol. 23, 93-99, 2015.

[148] F. Ge, M. M. Li, H. Ye, and B. X. Zhao, Effective removal of heavy metal ions $\mathrm{Cd}^{2+}, \mathrm{Zn}^{2+}, \mathrm{Pb}^{2+}$, $\mathrm{Cu}^{2+}$ from aqueous solution by polymer-modified magnetic nanoparticles, J Hazard Mater, vol. 211-212, 366-72, Apr 152012. 
[149] J. Wang, S. Zheng, Y. Shao, J. Liu, Z. Xu, and D. Zhu, Amino-functionalized $\mathrm{Fe}_{3} \mathrm{O}_{4} @ \mathrm{SiO}_{2}$ coreshell magnetic nanomaterial as a novel adsorbent for aqueous heavy metals removal, J Colloid Interface Sci, vol. 349, no. 1, 293-9, Sep 012010.

[150] M. Xie et al., Synthesis and adsorption behavior of magnetic microspheres based on chitosan/organic rectorite for low-concentration heavy metal removal, Journal of Alloys and Compounds, vol. 647, 892-905, 2015.

[151] M. A. Badawi, N. A. Negm, M. T. H. Abou Kana, H. H. Hefni, and M. M. Abdel Moneem, Adsorption of aluminum and lead from wastewater by chitosan-tannic acid modified biopolymers: Isotherms, kinetics, thermodynamics and process mechanism, Int J Biol Macromol, vol. 99, 465476, Jun 2017.

[152] M. Ahmad, S. Ahmed, B. L. Swami, and S. Ikram, Preparation and characterization of antibacterial thiosemicarbazide chitosan as efficient $\mathrm{Cu}(\mathrm{II})$ adsorbent, Carbohydr Polym, vol. 132, 164-72, Nov 052015.

[153] M. Ahmad, K. Manzoor, P. Venkatachalam, and S. Ikram, Kinetic and thermodynamic evaluation of adsorption of $\mathrm{Cu}(\mathrm{II})$ by thiosemicarbazide chitosan, Int J Biol Macromol, vol. 92, 910-919, Nov 2016.

[154] A. Labidi, A. M. Salaberria, S. C. M. Fernandes, J. Labidi, and M. Abderrabba, Adsorption of copper on chitin-based materials: Kinetic and thermodynamic studies, Journal of the Taiwan Institute of Chemical Engineers, vol. 65, 140-148, 2016.

[155] G. Annadurai, L. Y. Ling, and J. F. Lee, Adsorption of reactive dye from an aqueous solution by chitosan: isotherm, kinetic and thermodynamic analysis, J Hazard Mater, vol. 152, no. 1, 337-46, Mar 212008.

[156] A. O. Hiroyuki Yoshida, Adsorption Of Acid Dye on Cross-Linked Chitosan Fibers: Equilibra, Chemical Engineering Science, vol. 48, no. 12, 2261-2272, 25 November 19921993.

[157] H. Yan, L. Yang, Z. Yang, H. Yang, A. Li, and R. Cheng, Preparation of chitosan/poly(acrylic acid) magnetic composite microspheres and applications in the removal of copper (II) ions from aqueous solutions, J Hazard Mater, vol. 229-230, 371-80, Aug 302012.

[158] S. Zhang, Y. Zhou, W. Nie, L. Song, and T. Zhang, Preparation of Uniform Magnetic Chitosan Microcapsules and Their Application in Adsorbing Copper Ion(II) and Chromium Ion(III), Industrial \& Engineering Chemistry Research, vol. 51, no. 43, 14099-14106, 2012.

[159] M. P. Herrling et al., Low biosorption of PVA coated engineered magnetic nanoparticles in granular sludge assessed by magnetic susceptibility, Science of The Total Environment, vol. 537, 43-50, 2015.

[160] D. H. K. Reddy and S.M. Lee, Application of magnetic chitosan composites for the removal of toxic metal and dyes from aqueous solutions, Advances in Colloid and Interface Science, vol. 201-202, no. Supplement C, 68-93, 2013/12/01/ 2013.

[161] K. Z. Elwakeel, A. A. Atia, and E. Guibal, Fast removal of uranium from aqueous solutions using tetraethylenepentamine modified magnetic chitosan resin, Bioresour Technol, vol. 160, 107-14, May 2014.

[162] Y. Zhu, J. Hu, and J. Wang, Competitive adsorption of $\mathrm{Pb}(\mathrm{II}), \mathrm{Cu}$ (II) and $\mathrm{Zn}$ (II) onto xanthatemodified magnetic chitosan, J Hazard Mater, vol. 221-222, 155-61, Jun 302012.

[163] Y. Zhu, Z. S. Bai, and H.L. Wang, Microfluidic synthesis of thiourea modified chitosan microsphere of high specific surface area for heavy metal wastewater treatment, Chinese Chemical Letters, vol. 28, no. 3, 633-641, 2017.

[164] F. Zhao, E. Repo, D. Yin, and M. E. Sillanpää, Adsorption of Cd(II) and Pb(II) by a novel EGTAmodified chitosan material: Kinetics and isotherms, Journal of colloid and interface science, vol. 409, 174-182, 2013. 
[165] S. Hydari, H. Sharififard, M. Nabavinia, and M. reza Parvizi, A comparative investigation on removal performances of commercial activated carbon, chitosan biosorbent and chitosan/activated carbon composite for cadmium, Chemical engineering journal, vol. 193, 276-282, 2012.

[166] N. A. Negm, R. El Sheikh, A. F. El-Farargy, H. H. H. Hefni, and M. Bekhit, Treatment of industrial wastewater containing copper and cobalt ions using modified chitosan, Journal of Industrial and Engineering Chemistry, vol. 21, no. Supplement C, 526-534, 2015/01/25/ 2015.

[167] W. Jiang et al., Spherical polystyrene-supported chitosan thin film of fast kinetics and high capacity for copper removal, Journal of hazardous materials, vol. 276, 295-301, 2014.

[168] M. G. Mahfouz et al., Uranium extraction using magnetic nano-based particles of diethylenetriaminefunctionalized chitosan: equilibrium and kinetic studies, Chemical Engineering Journal, vol. 262, 198-209, 2015.

[169] M. Benavente, L. Moreno, and J. Martinez, Sorption of heavy metals from gold mining wastewater using chitosan, Journal of the Taiwan Institute of Chemical Engineers, vol. 42, no. 6, 976-988, 2011.

[170] A. C. Chao, S. H. Yu, and G. S. Chuang, Using NaCl particles as porogen to prepare a highly adsorbent chitosan membranes, Journal of Membrane Science, vol. 280, no. 1-2, 163-174, 2006.

[171] D. E. S. Santos, C. G. T. Neto, J. L. C. Fonseca, and M. R. Pereira, Chitosan macroporous asymmetric membranes - Preparation, characterization and transport of drugs, Journal of Membrane Science, vol. 325, no. 1, 362-370, 2008.

[172] A. Ghaee, M. Shariaty-Niassar, J. Barzin, and T. Matsuura, Effects of chitosan membrane morphology on copper ion adsorption, Chemical Engineering Journal, vol. 165, no. 1, 46-55, 2010.

[173] A. Ghaee, M. Shariaty-Niassar, J. Barzin, and A. Zarghan, Adsorption of copper and nickel ions on macroporous chitosan membrane: Equilibrium study, Applied Surface Science, vol. 258, no. 19, 7732-7743, 2012.

[174] F. A. Bertoni, J. C. González, S. I. García, L. F. Sala, and S. E. Bellú Application of chitosan in removal of molybdate ions from contaminated water and groundwater, Carbohydrate Polymers, vol. $180,55-62,2018$.

[175] F. A. Bertoni, A. C. Medeot, J. C. Gonzalez, L. F. Sala, and S. E. Bellu, Application of green seaweed biomass for MoVI sorption from contaminated waters. Kinetic, thermodynamic and continuous sorption studies, J Colloid Interface Sci, vol. 446, 122-32, May 152015.

[176] C.H. Wu, Competitive adsorption of molybdate, chromate, sulfate, selenate, and selenite on g$\mathrm{Al}_{2} \mathrm{O}_{3}$, Colloids \& Surfaces, vol. 166, no. 2000, 251-259, 19 August 19991999.

[177] M. W. Wan, C. C. Kan, B. D. Rogel, and M. L. P. Dalida, Adsorption of copper (II) and lead (II) ions from aqueous solution on chitosan-coated sand, Carbohydrate Polymers, vol. 80, no. 3, 891-899, 2010.

[178] S. R. Popuri, Y. Vijaya, V. M. Boddu, and K. Abburi, Adsorptive removal of copper and nickel ions from water using chitosan coated PVC beads, Bioresour Technol, vol. 100, no. 1, 194-9, Jan 2009.

[179] M. J. Calagui, D. B. Senoro, C. C. Kan, J. W. Salvacion, C. M. Futalan, and M. W. Wan, Adsorption of indium (III) ions from aqueous solution using chitosan-coated bentonite beads, J Hazard Mater, vol. 277, 120-6, Jul 302014.

[180] P. Hu, J. Wang, and R. Huang, Simultaneous removal of $\mathrm{Cr}(\mathrm{VI})$ and Amido black 10B (AB10B) from aqueous solutions using quaternized chitosan coated bentonite, Int J Biol Macromol, vol. 92, 694-701, Nov 2016.

[181] F. Ferrero, C. Tonetti, and M. Periolatto, Adsorption of chromate and cupric ions onto chitosancoated cotton gauze, Carbohydr Polym, vol. 110, 367-73, Sep 222014.

[182] N. Guo, S. J. Su, B. Liao, S. L. Ding, and W. Y. Sun, Preparation and properties of a novel macro porous Ni2+-imprinted chitosan foam adsorbents for adsorption of nickel ions from aqueous solution, Carbohydr Polym, vol. 165, 376-383, Jun 012017. 
[183] X. Wu et al., Preparation of aligned porous gelatin scaffolds by unidirectional freeze-drying method, Acta Biomaterialia, vol. 6, no. 3, 1167-1177, 2010/03/01, 2010.

[184] M. Seredych and T. J. Bandosz, Graphite oxide/AlZr polycation composites: Surface characterization and performance as adsorbents of ammonia, Materials Chemistry and Physics, vol. 117, no. 1, 99-106, 2009/09/15, 2009.

[185] J. Zhang, Z. H. Huang, R. Lv, Q. H. Yang, and F. Kang, Effect of Growing CNTs onto Bamboo Charcoals on Adsorption of Copper Ions in Aqueous Solution, Langmuir, vol. 25, no. 1, 269-274, 2009/01/06, 2009.

[186] Y. Q. He, N. N. Zhang, and X. D. Wang, Adsorption of graphene oxide/chitosan porous materials for metal ions, Chinese Chemical Letters, vol. 22, no. 7, 859-862, 2011.

[187] P. Pal and F. Banat, Comparison of heavy metal ions removal from industrial lean amine solvent using ion exchange resins and sand coated with chitosan, Journal of Natural Gas Science and Engineering, vol. 18, 227-236, 2014.

[188] S. S. Salih and T. K. Ghosh, Adsorption of Zn(II) ions by chitosan coated diatomaceous earth, Int J Biol Macromol, Aug 122017.

[189] J. Zhao et al., Chitosan-coated mesoporous microspheres of calcium silicate hydrate: environmentally friendly synthesis and application as a highly efficient adsorbent for heavy metal ions, J Colloid Interface Sci, vol. 418, 208-15, Mar 152014. 